\title{
Holmes, Cardozo, and the Legal Realists: Early Incarnations of Legal Pragmatism and Enterprise Liability
}

\author{
EDMUND URSIN*
}

\section{TABLE OF CONTENTS}

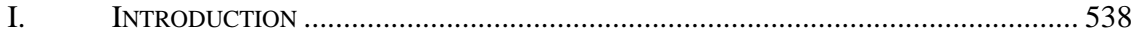

II. Setting The Stage: ToRT And Constitutional LaW AT the TURN

OF THE TWENTIETH CENTURY ........................................................................... 545

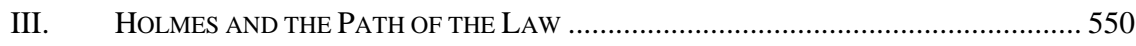

A. Holmes and the Need for Judicial Creativity in Common

Law Subjects .................................................................................. 550

B. The Path Not Followed …….............................................................. 554

IV. THE INDUSTRIAL ACCIDENT CRISIS, THE WORKERS’ COMPENSATION

SOLUTION, AND A CONSTITUTIONAL CONFRONTATION ……................................. 558

A. The Industrial Accident Crisis and the Workers'

Compensation Solution

* $\quad$ (C) 2013 Edmund Ursin. Professor of Law, University of San Diego School of Law. Thanks to Richard Posner for valuable comments on an earlier draft of this Article and to Roy Brooks and Kevin Cole for always helpful comments on previous articles upon which I expand in this Article. See Edmund Ursin, Clarifying the Normative Dimension of Legal Realism: The Example of Holmes's The Path of the Law, 49 SAN Diego L. ReV. 487 (2012) [hereinafter Ursin, Clarifying]; Edmund Ursin, The Missing Normative Dimension in Brian Leiter's "Reconstructed" Legal Realism, 49 SAN DIEGO L. REV. 1 (2012) [hereinafter Ursin, Missing Dimension]. The Article also benefited from excellent research assistance from Laura Kruberg and Narie Oh. Permission is hereby granted to duplicate this paper for scholarly or teaching purposes, including permission to reproduce multiple copies or post on the Internet, and to quote extended passages in scholarly work, including casebooks and anthologies, subject only to the requirement that this copyright notice, the title of the Article, and the name of the Author be prominently included in the copy or extended excerpt. 
B. A “Revolutionary” Solution Collides with Lochner-Style Jurisprudence ...

V. MACPHERSON V. BUICK AND THE JUDICIAL REFORM OF THE

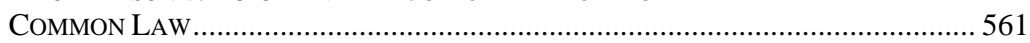

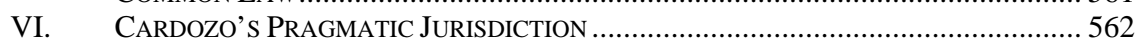

A. Cardozo on Judicial Lawmaking ......................................................... 562

B. $\quad$ The Role of Logic, History, and Custom ................................................ 562

C. Cardozo's Legal Pragmatism ................................................................ 564

D. Cardozo's Reticent Jurisprudence: MacPherson and Ives/Jensen Revisited . 568

VII. LEON GREEN AND KARL LLEWELLYN: LEGAL REALISM,

ENTERPRISE LIABILITY, AND LEGAL PRAGMATISM ……........................................ 572

A. $\quad$ The Transition to Legal Realism/Enterprise Liability............................. 572

B. The Legal Realists' Constitutional Restraint and Common Law Creativity ............................................................................ 576

C. Leon Green's Legal Realism and Enterprise Liability.......................... 577

D. Karl Llewellyn's Legal Realism and Strict Products Liability.......

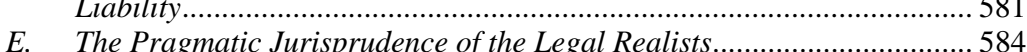

VIII. LEgAL PRAGMATISM AND ENTERPRISE LiABILITY IN THE COURTS ......................... 585

\section{INTRODUCTION}

The theory of enterprise liability is associated with the tort lawmaking of the liberal California Supreme Court of the 1960s and 1970s. ${ }^{1}$ Legal pragmatism, in turn, is associated with the conservative jurist Richard Posner. $^{2}$ This Article explains that early incarnations of each can be found in the works of four giants in American law: Justice Oliver Wendell Holmes, Judge-later Justice-Benjamin Cardozo, and the Legal Realists Leon Green and Karl Llewellyn. As will be seen, these scholars and judges shared a common view of the lawmaking role of courts. Stated simply, this shared view was that judges are lawmakers and policy does - and should — shape their lawmaking. If this formulation sounds familiar, it is because of its similarity to Judge Richard Posner's legal pragmatism, which Posner himself has linked to Holmes and Cardozo. Posner's legal pragmatist believes that at times "judges in our

1. See Virginia E. Nolan \& EDMUnd URsin, Understanding EnTERPRISE LIABILITY: RETHINKING TORT REFORM FOR THE TWENTY-FIRST CENTURY 116-22 (1995); Edmund Ursin, How Great Judges Think: Judges Richard Posner, Henry Friendly, and Roger Traynor on Judicial Lawmaking, 57 BuFF. L. REV. 1267, 1291, 1296-97 (2009).

2. See, e.g., RichARD A. Posner, HOW Judges THINK 118, 238 (2008); see also Lee Epstein, William M. Landis \& Richard A. Posner, The Behavior of Federal JUDGES (2013) (presenting and testing empirically a theory of behavior of federal judges); Ursin, supra note 1, at 1279-90 (discussing Posner's legal pragmatism). 
system are legislators as well as adjudicators" and that policy judgments are at the core of their lawmaking. ${ }^{3}$

A particular focus of this Article will be judicial lawmaking in the common law and, more specifically, tort law. This focus reveals that we can see in the works of these great judges and scholars the origins of the enterprise liability doctrines adopted by courts in recent decades, in particular, the doctrine of strict products liability and the policy-based expansion of liability within the negligence system.

We begin, in Part II, following this introduction, with a brief examination of the crisis in workplace accidents at the turn of the twentieth century, as widows, orphans, and injured workers vainly sought compensation through a-pre-workers' compensation—-tort system. ${ }^{4}$ That tort system was a product of mid-nineteenth century judges who had felt free to craft tort doctrines to meet the felt necessities of their time. For example, decisions by judges, such as Chief Justice Lemuel Shaw of Massachusetts, had established the negligence requirement, as well as the fellow servant rule and the doctrines of contributory negligence and assumption of risk. Taken together, these stalwarts of what might be called traditional tort theory often left injured workers and their families with no legal remedy against employers and thus without any practical hope of compensation.

One might have thought that later judges would adapt tort common law to the felt necessities of their time, just as judges like Lemuel Shaw had done for theirs. By the late nineteenth century, however, judges no longer saw this as their role. These formalist judges maintained that courts do not and should not "make law."

In reality, however, these formalist judges were active lawmakers. Around the turn of the twentieth century and for the next four decades, during what is known as the Lochner era, after the Supreme Court's 1905 decision in Lochner v. New York, ${ }^{5}$ the courts of this country, including the United States Supreme Court, invoked the United States

3. PosNer, supra note 2, at 13, 118, 238. For a recent statement of eight principles of legal pragmatism, see Richard A. Posner, The Rise and Fall of Judicial Self-Restraint, 100 CALIF. L. REV. 519, 540-42 (2012).

4. See CRystal EASTMAN, WORK-ACCIDENTS AND THE LAW 121-23 (1910). See generally JOHN FABIAN WiTt, THE ACCIDENTAL REPUBliC: CRIPPLED WORKINGMEN, DESTITUTE WidOWS, AND THE REMAKING OF AMERICAN LAW (2004) (providing a legal history of employee accident law and the adoption of workers' compensation legislation).

5. 198 U.S. 45 (1905). 
Constitution, and especially the Due Process Clause of the Fourteenth Amendment, "to strike down laws fixing minimum wages and maximum hours in employment, laws fixing prices, and laws regulating business activities." 6

For some, the lesson of Lochner was that courts should refrain from the sort of policy-based lawmaking that I have attributed to our great judges and scholars. ${ }^{7}$ Indeed, in his famous Lochner dissent, Holmes wrote, "This case is decided upon an economic theory which a large part of the country does not entertain." ${ }^{\text {A }}$ And he felt compelled to remind the Court that "a constitution is not intended to embody a particular economic theory, whether of paternalism and the organic relation of the citizen to the State or of laissez faire." " One might interpret this as a warning against policy-based judicial lawmaking.

However, that would be to misread Holmes. Thus, after our brief look at the state of the American legal system at the turn of the twentieth century, we turn in Part III to Holmes's famous 1897 essay, The Path of the Law. ${ }^{10}$ There we find that far from being critical of policy-based lawmaking by courts, Holmes chastised courts of that era for their lack of just such lawmaking. Focusing on the law of worker accidents, Holmes first noted the "inclination of a very large part of the community ... to make certain [well-known businesses] insure the safety of those with whom they deal."11 Then turning to the lawmaking role of the courtsand setting aside how he would decide the substantive issue if it were presented to him-Holmes suggested that courts might properly rewrite the pre-workers' compensation tort law governing workplace accidents. ${ }^{12}$ For Holmes, there was nothing anomalous in recognizing the role of policy in the common law, where the legislature can always unwrite the law the courts have written, while calling for judicial self-restraint when the legislature has spoken. In fact, anticipating decisions like Lochner, Holmes made precisely this point in The Path of the Law, writing that courts cognizant of the policies at stake should hesitate in constitutional adjudication to overturn legislation. ${ }^{13}$

6. Lincoln Fed. Labor Union v. Nw. Iron \& Metal Co., 335 U.S. 525, 535

7. See, e.g., Warren A. Seavey, Mr. Justice Cardozo and the Law of Torts, 52 HaRV. L. ReV. 372, 372-73 (1939); 39 Colum. L. ReV. 20, 20-21 (1939); 48 YALE L.J. 390, 390-91 (1939) [hereinafter citing to HARV. L. REV.].

8. Lochner, 198 U.S. at 75 (Holmes, J., dissenting).

9. Id.

10. O. W. Holmes, The Path of the Law, 10 HARV. L. REv. 457 (1897).

11. Id. at 466 .

12. Id. at 466-67. I first discussed this in Edmund Ursin, Judicial Creativity and Tort Law, 49 GeO. WASH. L. REV. 229, 271-75 (1981).

13. See Holmes, supra note 10, at 467-68. 
Although courts did not rewrite the law of employee accidents, legislatures did. As discussed in Part IV, New York responded to the workplace accident crisis in 1910 by enacting the nation's first workers' compensation legislation. ${ }^{14}$ That legislation, which dispensed with the fault requirement, was a landmark event in personal injury law-and, as we will see, the inspiration for the enterprise liability doctrines that Green and Llewellyn would urge courts to adopt twenty years later. But this is to jump ahead.

The immediate response of the New York Court of Appeals was far different. In 1911, the year following the enactment of the legislation, the New York Court of Appeals held in Ives v. South Buffalo Railway Co. that the legislation violated the due process clauses of both the New York and United States Constitutions by dispensing with the fault requirement. ${ }^{15}$ The Ives decision unleashed public wrath and "a storm of disapproval," causing, along with the Supreme Court's Lochner decision, "the greatest court controversy since Dred Scott."16 The voters of New York quickly responded to Ives by enacting, in 1913, a constitutional amendment authorizing the state legislature to enact workers' compensation legislation, which the legislature promptly did. ${ }^{17}$ The New York Court of Appeals, in turn, did a turnabout in 1915 by upholding the new legislation in Jensen v. Southern Pacific Co., overruling Ives by finding that the new legislation did not violate the Federal Constitution. ${ }^{18}$

Benjamin Cardozo was appointed to the New York Court of Appeals in 1913, two years after the Ives decision, and thus sat on that court as it changed course in Jensen. ${ }^{19}$ Then, in 1916, as discussed in Part V, Cardozo issued his decision in MacPherson v. Buick Motor Co., marking a second landmark event in twentieth-century personal injury law, made all the more remarkable by the five tumultuous years that preceded it. ${ }^{20}$ MacPherson paved the way for the elimination of the privity requirement

14. See Lawrence M. Friedman \& Jack Ladinsky, Social Change and the Law of Industrial Accidents, 67 CoLuM. L. REV. 50, 68 (1967).

15. See 94 N.E. 431, 439-40 (N.Y. 1911).

16. WITT, supra note 4 , at 152 .

17. Id. at 176 (citing N.Y. CoNST. art. I, § 18).

18. 109 N.E. 600, 602, 604 (N.Y. 1915).

19. See Richard A. Posner, Cardozo: A Study in Reputation 2-3 (1990) ("After only a month on the state supreme court, he was breveted to the New York Court of Appeals ....."). He was elected to that position in 1917. Id. at 3.

20. 111 N.E. 1050 (N.Y. 1916). 
in negligence suits involving injury from defective products ${ }^{21}$ —and, Justice Traynor would later argue, could provide a bridge to the doctrine of strict products liability. ${ }^{22}$

Following the discussion of these seminal events, the Article turns in Part VI to Cardozo's major jurisprudential work, The Nature of the Judicial Process, which was published in 1921 after being given as a series of lectures at Yale Law School. ${ }^{23}$ Judge Posner has written that Cardozo presented "the classic full-blown exposition of the pragmatic position sketched by Holmes," and he is correct. ${ }^{24}$ The Nature of the Judicial Process is an eloquent and nuanced treatment of legal pragmatism. Holmes notwithstanding, however, the dominant view at the time Cardozo wrote was that courts do not make law and that policy plays no role in their decisionmaking. ${ }^{25}$ Echoing themes developed by Holmes, Cardozo rejected this view, writing that "the function of our courts [is] ... to keep the doctrines up to date with the mores by continual restatement and by giving them a continually new content."26 Common law judges must innovate, "for with new conditions there must be new rules." 27 "This means ... that the juristic philosophy of the common law is at bottom the philosophy of pragmatism."28 Like Holmes, Cardozo also took Lochner-era courts to task for their lack of deference to the

21. At the time MacPherson was decided, a person injured by a negligently manufactured product had no tort action against the manufacturer if, as was most often the case, the product had been purchased from a dealer, as opposed to the manufacturer. See Sally H. Clarke, Unmanageable Risks: MacPherson v. Buick and the Emergence of a Mass Consumer Market, 23 LAW \& HIST. REV. 1, 3 (2005). An exception to this privity requirement had been established, however, for products that were imminently dangerous to life or health. Id. In MacPherson, the imminently dangerous exception was so expansively interpreted that by the end of the opinion it was on its way to becoming the rule for all products. See MacPherson, 111 N.E. at 1053; see, e.g., Brian Leiter, In Praise of Realism (and Against "Nonsense” Jurisprudence), 100 GEO. L.J. 865, 880 (2012).

22. Escola v. Coca Cola Bottling Co., 150 P.2d 436, 440 (Cal. 1944) (Traynor, J., concurring).

23. Benjamin N. Cardozo, The Nature of the Judicial Process (1921); see also Arthur L. Corbin, The Judicial Process Revisited: Introduction, 71 YALE L.J. 195, 195 (1961) (noting that Justice Cardozo authored "four lectures entitled The Nature of the Judicial Process that were delivered at Yale").

24. Posner, supra note 19, at 21. Judge Posner also notes, however, that "with the aid of hindsight almost everything in The Nature of the Judicial Process can be found in embryo form somewhere in Holmes's voluminous writings." Id.

25. See Seavey, supra note 7, at 372-73.

26. CARDOZO, supra note 23, at 135 (quoting Arthur L. Corbin, The Offer of an Act for a Promise, 29 YALE L.J. 767, 771 (1920)) (internal quotation marks omitted).

27. Id. at 137.

28. Id. at 102 (citing Roscoe Pound, Mechanical Jurisprudence, 8 CoLUM. L. REV. 605, 609 (1908)). 
legislative process, writing that it was Holmes's dissent to "which men will turn to in the future as the beginning of an era."29

Although the enactment of workers' compensation legislation and Cardozo's own MacPherson decision were the two most important developments in the personal injury law of the first half of the twentieth century, Cardozo, curiously, did not comment extensively on either-or on his court's Ives and Jensen decisions. Nor did he speculate about the implications of these developments for the future of personal injury law. These matters, however, would shape the thinking of two seminal Legal Realists of the next generation: Leon Green and Karl Llewellyn, to whose work we turn in Part VII.

Green and Llewellyn followed the lead of Holmes and Cardozo in their opposition to Lochner-era constitutional decisions. But this was not their focus, nor really was the process of judicial lawmaking-aside from Llewellyn's well-known writings on Legal Realism. ${ }^{30}$ Green's focus was tort law, and Llewellyn's was contract and sales law. When Green and Llewellyn wrote about their respective subjects, each recognized, contrary to the still dominant legal formalism of their time, the reality, inevitability, and desirability of judicial lawmaking. In addition, each recognized the central role that policy plays in that process. Green's and Llewellyn's substantive writings revealed a jurisprudential view that was

29. Id. at 79 .

30. See, e.g., Karl N. Llewellyn, A Realistic Jurisprudence-The Next Step, 30 Colum. L. Rev. 431, 431 (1930). Llewellyn's article and other Legal Realists' works drew a rebuke from Roscoe Pound for their perceived radicalism. See Roscoe Pound, The Call for a Realist Jurisprudence, 44 HARV. L. REV. 697, 697-99 (1931). Llewellyn swiftly responded. See Karl N. Llewellyn, Some Realism About Realism-Responding to Dean Pound, 44 Harv. L. REV. 1222, 1223-25 (1931). In 1932, on the eve of his appointment to the United States Supreme Court, Cardozo gave an address to a meeting of the New York State Bar Association in which he sought-unsuccessfully - to mediate between the two sides and to "moderate what he saw as the nihilist tendencies of some realists, especially their exaggeration of the indeterminacy of legal principles." ANDREW L. KAUFMAN, CARDOZO 456 (1998) (discussing Benjamin N. Cardozo, Jurisprudence, in Selected Writings of Benjamin Nathan Cardozo 7-46 (Margaret E. Hall ed., 1947)); see also Karl N. LleWellyn, The Common LaW Tradition: Deciding APPEALS app. B at 508-12 (1960) (discussing interpretations of American Legal Realism). Llewellyn's book was criticized by Judge Charles E. Clark and David Trubek on the ground that it "recognizes judicial creativity as part of the common law tradition, but seems ... to reject the notion of judicial freedom which was the starting point for Cardozo's fourth method of decision-the method of social value, or the judge as a legislator.” Charles E. Clark \& David M. Trubek, The Creative Role of the Judge: Restraint and Freedom in the Common Law Tradition, 71 YALE L.J. 255, 256 (1961). 
simple and clear: in the common law realm, courts (1) do make law, and (2) such lawmaking is so obviously desirable, necessary, and in our common law tradition that it needed no fancy jurisprudential justificationbeyond, that is, arguments as to the substantive desirability of particular proposals.

Green and Llewellyn believed, as Brian Leiter has written about Legal Realists generally, that legal decisions fall into patterns determined more by "situation types" than by formal legal rules. ${ }^{31}$ But contrary to Leiter, Green and Llewellyn also put forth a robust normative agenda-and, in doing so, laid the foundations for the enterprise liability doctrines that courts would adopt decades later. ${ }^{32}$

In Green's view, “[t]he idea of 'fault,"” the cornerstone of traditional tort theory, had become bankrupt. ${ }^{33}$ In its place Green offered policy, or "dut[y]," factors to determine common law duty and liability rules - and whether compensation plans modeled after workers' compensation plans should displace tort in discrete categories of accidents. ${ }^{34}$ Perhaps most provocative was Green's suggestion that loss spreading capacity should be a legitimate factor in fashioning liability rules, which he linked to the proposal that courts single out industrial premises cases for special consideration, including the possibility of replacing the no-duty rules that protected landowners from liability with a full duty of care. ${ }^{35}$

For his part, Llewellyn saw the law of sales, and in particular the implied warranty of quality that attaches to the sale of goods, as a source for courts to use in developing a doctrine of strict products liability. ${ }^{36}$ The "needed protection," Llewellyn wrote, "is twofold: to shift the immediate incidence of the hazard of life in an industrial society away from the individual over to a group which can distribute the loss; and to place the loss where the most pressure will be exerted to keep down future losses. ${ }^{37}$

31. Brian Leiter, Positivism, Formalism, Realism, 99 Colum. L. Rev. 1138, 1148 (1999) (internal quotation marks omitted) (reviewing ANTHONY SEBOK, LEGAL POSITIVISM IN AMERICAN JURISPRUDENCE (1998)).

32. See, e.g., Ursin, Clarifying, supra note * at 488; Ursin, Missing Dimension, supra note * at 4.

33. Leon Green, The Duty Problem in Negligence Cases: II, 29 Colum. L. REv. 255, 270 (1929).

34. Id. at 255-57.

35. Id. at $273-75$.

36. See Karl N. Llewellyn, Cases and Materials on the Law of Sales 34142 (1930); K. N. Llewellyn, On Warranty of Quality, and Society, 36 CoLUM. L. ReV. 699, 704 n.14 (1936).

37. LLEWELLYN, supra note 36, at 341. 
Judges acting in the manner suggested by Green and Llewellyn would be engaged in what a contemporary of theirs termed "juristic pragmatism."38 To use Judge Posner's terminology, they were legal pragmatists who believed that judges are "legislators as well as adjudicators" with policy at the core of their lawmaking. ${ }^{39}$ As discussed in Part VIII, the concluding section of this Article, this is the role the California Supreme Court-the nation's leading state supreme court ${ }^{40}$ - has assumed since the $1960 \mathrm{~s}$, as it has written the methodology and doctrines suggested by Green and Llewellyn into law. ${ }^{41}$

\section{SetTing The Stage: Tort And Constitutional LAW AT THE TURN OF THE TWENTIETH CENTURY}

By the turn of the twentieth century, the United States had become an industrial nation. To take one example, the railroad industry had come into its own by that date. Mileage figures indicate its success. In 1840, total track mileage in America was less than 3000 miles. The subsequent success of the railroad was spectacular. "Railway mileage climbed from about 35,000 in 1865 to 74,000 in 1875 , to 128,000 in 1885 , to about 190,000 by 1900 - a 600 per cent growth in 35 years." 42 Similarly, business enterprises that had once been small and struggling had become large corporations. "By 1904 manufacturing companies producing over $\$ 1$ million of value added in manufacturing were less than one per cent of all such concerns, but accounted for about 30 per cent of the total value added by manufacturing." 43 Moreover, corporate consolidation was rampant. "From 1890 to 1904 some 237 corporate consolidations occurred, each involving business of regional or national extent, each capitalized for more than $\$ 1$ million, representing almost every important field of manufacture." 44

38. See Fowler Vincent Harper, Some Implications of Juristic Pragmatism, 39 INT’L J. ETHICS 269, 290 (1929).

39. See Posner, supra note 2, at 13, 118, 238.

40. See Jake Dear \& Edward W. Jessen, "Followed Rates” and Leading State Cases, 1940-2005, 41 U.C. DAVIS L. REV. 683, 710 (2007).

41. See Ursin, supra note 1, at 1335-38; Ursin, Missing Dimension, supra note * at 32-35.

42. James Willard Hurst, LaW and the Conditions of Freedom in the NiNETEENTH-CENTURY UNITED STATES 72 (1956).

43. Id. at 71-72.

44. Id. at 72; see also Richard Hofstadter, THE Age of REFORM: From Bryan TO F.D.R. 230 (1955) (“[T]he interlocking directorates of American corporations 
As industry grew, however, so did the number of injuries associated with it. John Fabian Witt has written that at the turn of the twentieth century, the United States "was in the fifth decade of an accident crisis like none the world had ever seen and like none any Western nation has witnessed since.”45 Between 1889 and 1906, for example, the railway injury rate doubled. ${ }^{46}$ At the turn of the century, industrial accidents accounted for 35,000 deaths and 2,000,000 injuries each year. ${ }^{47}$ "One quarter of [these] injuries produced disabilities lasting more than one week." 48 “[O]ne worker in fifty was killed or disabled for at least four weeks each year because of a work-related accident. Among the population as a whole, roughly one in every thousand Americans died in an accident each year." 49 The historian Richard Hofstadter reminds us that "[t]oday it is perhaps necessary to make a strong effort of the imagination to recall the industrial barbarism that was being tamed [during that era] ... when every year some 16,000 or 17,000 trainmen (about one out of every ten or twelve workers so classified) were injured."50

The social problem presented by industrial accidents was due in large part to the lawmaking of judges of the mid-nineteenth century who had felt free to craft tort doctrines to meet the felt necessities of their time. Decisions by Chief Justice Lemuel Shaw of Massachusetts, for example, had established the negligence requirement, the fellow servant rule, and the doctrines of contributory negligence and assumption of risk. ${ }^{51}$ Taken together, these stalwarts of traditional tort theory often left injured workers with no legal remedy against their employer and thus without any practical hope of compensation.

[showed] that fewer than one hundred men, acting in concert, controlled the great business interests of the country.”); Max Lerner, The Triumph of Laissez-Faire, in PATHS of American Thought 147, 147-49 (Arthur M. Schlesinger, Jr. \& Morton White eds., 1963) ("The spreading power of corporations [in the late nineteenth century] produced a new corporate elite, with a talent for combining formerly independent operations .....). See generally ARTHur CeCIL Bining \& ThOMAs C. Cochran, THE Rise of AMERICAN ECONOMIC LiFE (4th ed. 1964); ARTHUR F. BuRns, PRODUCTION TRENDS IN THE UNITED States Since 1870 (1934); Alex Groner, The American Heritage History of AMERICAN Business \& INDUSTRY (Alvin M. Josephy, Jr. ed., 1972).

45. WITT, supra note 4 , at 2 .

46. Friedman \& Ladinsky, supra note 14, at 60.

47. Id.

48. Id. (citing E.H. DOWNEY, History OF WORK ACCIDENT INDEMNITY IN IOWA 1$2(1912))$.

49. WITT, supra note 4, at 2-3 (citing Frederick Hoffman, Industrial Accident Statistics, Bull. U.S. Bureau LaB. Stat., Mar. 1915, at 5-6, 13).

50. HOFSTADTER, supra note 44, at 240.

51. Brown v. Kendall, 60 Mass. (6 Cush.) 292, 297-98 (1850) (establishing negligence standard and contributory negligence doctrine); Farwell v. Bos. \& Worcester R.R., 45 Mass. (4 Met.) 49, 55-61 (1842) (adopting fellow servant and assumption of risk doctrines). 
A study conducted by Crystal Eastman for the Russell Sage Foundation and published in 1910 illustrates the situation with a detailed examination of Pittsburgh and Allegheny County. ${ }^{52}$ In instances of work-related accident fatalities, widows and children were given little or no assistance by the legal system. In the majority of cases, widows and children bore the entire income loss. ${ }^{53}$ In fewer than one third of the cases did an employer pay as much as five hundred dollars. ${ }^{54}$ A similar situation prevailed when an employee was injured but not killed. More than half of these workers received no compensation, and only five percent were fully compensated for their lost working time while disabled. The study concluded that the result was "[n]ot hardship alone, but hardship [as] an outcome of injustice." 55

Indeed, the problem was so great that President Theodore Roosevelt made it the focal point of a major 1907 speech. In that speech, Roosevelt told his audience that "[t]he great increase in mechanical and manufacturing operations ... means a corresponding increase in the number of accidents to the wage-workers employed therein."56 "[I]t is a bitter injustice," Roosevelt continued, "that it should be the wage-worker himself and his wife and children who bear the whole penalty." 57

One might have thought that courts would ameliorate this "bitter injustice" by adapting the common law of torts to the felt necessities of their time just as judges like Lemuel Shaw had done for theirs. By the late nineteenth century, however, judges no longer saw this as their role. These judges maintained that courts do not and should not "make law." Most judges "saw their task ... as the preservation of the logical structure of the rules and fundamental principles of the law." 58 As Holmes

52. EASTMAN, supra note 4, at 6 . Similar studies were made of conditions in other geographic areas. See, e.g., Ives v. S. Buffalo Ry. Co., 94 N.E. 431, 435 (N.Y. 1911). See generally Friedman \& Ladinsky, supra note 14 (exploring the "concept of social change and illustrating its relationship to change in the law").

53. EASTMAN, supra note 4, at 121-22.

54. Id. at 121-23.

55. Id. at 152, quoted in Jerold S. AUERBACH, UNEQUAL JusticE: LAWYERS AND SOCIAL CHANGE IN MODERN AMERICA 44 (1976).

56. WITT, supra note 4, at 2 (quoting Proud of His Georgian Ancestry, Roosevelt Pays Glowing Tribute to South and Its Marvelous Progress. Automatic Indemnity for Personal Injury, WAsH. Post, June 11, 1907, at 11) [hereinafter Proud of His Georgian Ancestry] (internal quotation marks omitted).

57. Id. at 3 (quoting Proud of His Georgian Ancestry, supra note 56, at 11) (internal quotation marks omitted).

58. William E. Nelson, The Impact of the Antislavery Movement upon Styles of Judicial Reasoning in Nineteenth Century America, 87 HARV. L. REV. 513, 515 (1974). One scholar has suggested that the late nineteenth and early twentieth century doctrinal 
himself wrote, these formalist judges did "not like to discuss questions of policy." 59 Rather, they treated the judicial process as one of "logical deduction" and sought to make "legal reasoning seem like mathematics.",60

In reality, however, formalist judges were very active lawmakers. During the period around the turn of the century and for almost four decades into the twentieth century, the courts of this country, including the United States Supreme Court, invoked the United States Constitution, and especially the Due Process Clause of the Fourteenth Amendment, "to strike down laws fixing minimum wages and maximum hours in employment, laws fixing prices and laws regulating business activities.”61 This era has been called the Lochner era, named for the United States Supreme Court's 1905 decision that signaled the Court's explicit adoption of a policy of judicial intervention. ${ }^{62}$

Decisions of this era drew heated criticism. Foremost among the critics was Holmes. In his classic Lochner dissent, Holmes wrote, "This case is decided upon an economic theory which a large part of the country does not entertain." ${ }^{63}$ And he felt compelled to remind the Court that the "Fourteenth Amendment does not enact Mr. Herbert Spencer's Social Statistics." 64 Holmes wrote that "a constitution is not intended to embody a particular economic theory, whether of paternalism and the organic relation of the citizen to the State or of laissez faire." ${ }^{65}$ Holmes concluded that

change in tort law was influenced by intellectual pressure to articulate "scientific" principles, as well as by more widely recognized economic factors. See G. EDWARD White, TORT LAW IN AMERICA: AN INTELlECTUAl HistORy 20-62 (expanded ed. 2003); G. Edward White, The Impact of Legal Science on Tort Law, 1880-1910, 78 Colum. L. REV. 213, 213-14 (1978).

59. Oliver Wendell Holmes, Jr., Privilege, Malice, and Intent, 8 Harv. L. Rev. 1, 7 (1894).

60. Id.

61. Lincoln Fed. Labor Union v. Nw. Iron \& Metal Co., 335 U.S. 525, 535 (1949); see, e.g., Williams v. Standard Oil Co. of La., 278 U.S. 235, 245 (1929) (holding statute fixing price for gasoline sales in state unconstitutional); Tyson \& Brother United Theatre Ticket Offices, Inc. v. Banton, 273 U.S. 418, 444-45 (1927) (holding statute fixing maximum resale price for theater tickets contravened Fourteenth Amendment); Adkins v. Children's Hosp., 261 U.S. 525, 561-62 (1923) (holding statute fixing minimum wages for women and children unconstitutional); Pa. Coal Co. v. Mahon, 260 U.S. 393, 412-13, 416 (1922) (holding unconstitutional statute forbidding coal mining that in any way causes subsidence of human habitations).

62. See Lochner v. New York, 198 U.S. 45, 52, 64-65 (1905) (holding New York state law limiting work hours in bakeries to sixty per week or ten per day unconstitutional under the Due Process Clause of the Fourteenth Amendment).

63. Id. at 75 (Holmes, J., dissenting).

64. Id.

65. Id. 
the word liberty in the Fourteenth Amendment is perverted when it is held to prevent the natural outcome of a dominant opinion, unless it can be said that a rational and fair man necessarily would admit that the statute proposed would infringe fundamental principles as they have been understood by the traditions of our people and our law. 66

Critics of the Lochner Court constantly drew upon Holmes's position. A prominent and early example is Roscoe Pound, who later served as dean of Harvard Law School for two decades. Writing in 1908, Pound denounced judges who purported to deduce results in cases from preexisting principles, a technique Pound called "mechanical jurisprudence." 67 This mechanical jurisprudence was fatally flawed precisely because it ignored the social reality to which legal rules must be applied. The decision in Lochner exemplified this judicial technique. In its place, Pound called for a "Sociological Jurisprudence,"68 which he defined as "the movement for the adjustment of principles and doctrines to the human conditions they are to govern rather than to assumed first principles." ${ }^{69}$ Not surprisingly, Pound saw Holmes's Lochner dissent not only as a source of his ideas but also as the best exposition of sociological jurisprudence in America. ${ }^{70}$

66. Id. at 76 .

67. Pound, supra note 28, at 605. Pound was a prolific writer whose work spanned half a century. For examples of his work bearing on the themes discussed in this Article, see generally Roscoe Pound, The Call for a Realist Jurisprudence, 44 HARV. L. Rev. 697 (1931); Roscoe Pound, The Theory of Judicial Decision (pts. 1-3), 36 HARV. L. Rev. 641, 802, 940 (1923) [hereinafter Judicial Decision]; Roscoe Pound, The Scope and Purpose of Sociological Jurisprudence (pts. 1 \& 2), 24 HARV. L. REV. 591 (1911), 25 Harv. L. ReV. 489 (1912); Roscoe Pound, Law in Books and Law in Action, 44 AM. L. Rev. 12 (1910); Roscoe Pound, The Need of a Sociological Jurisprudence, 19 Green BAg 607 (1907) [hereinafter Sociological Jurisprudence]; Roscoe Pound, Do We Need a Philosophy of Law?, 5 Colum. L. REV. 339 (1905). For a biography of Pound, see David Wigdor, Roscoe Pound: Philosopher of LAW (1974). See generally G. Edward White, From Sociological Jurisprudence to Realism: Jurisprudence and Social Change in Early Twentieth-Century America, 58 VA. L. REV. 999 (1972) (discussing movement from mechanical justice to sociological jurisprudence).

68. See Pound, Sociological Jurisprudence, supra note 67.

69. Roscoe Pound, Liberty of Contract, 18 YALE L.J. 454, 464 (1909).

70. See id. 


\section{HOLMES AND THE PATH OF THE LAW}

\section{A. Holmes and the Need for Judicial Creativity in Common Law Subjects}

Holmes's Lochner dissent is often seen as the starting point for discussions of the proper lawmaking role of courts. But before the Lochner dissent, there was Holmes's prescient 1897 essay, The Path of the Law. ${ }^{71}$ In that essay, Holmes not only foresaw the coming of Lochnerlike decisions but also suggested the path that twentieth-century accident law might take. ${ }^{72}$ In doing so, he laid out his view of the lawmaking role of courts both in common law subjects and in constitutional decisions. ${ }^{73}$

Even as traditional tort theory flourished and courts began to embrace the formalism - and substance - of what was to become the Lochner era, an alternative view emerged, and its spokesperson was Holmes himself. Perhaps obscured by the prominence of his Lochner dissent is that Holmes's view of judicial lawmaking can be seen as an articulation and extension of Chief Justice Lemuel Shaw's conception of the lawmaking role of courts. ${ }^{74}$ In The Common Law, Holmes wrote of Shaw that "the strength of that great judge lay in an accurate appreciation of the requirements of the community whose officer he was." ${ }^{75}$ Although Holmes conceded that "[s]ome, indeed many, English judges could be named who have surpassed him in accurate technical knowledge," he argued that "few have lived who were his equals in their understanding of the grounds of public policy to which all laws must ultimately be referred." "76 He concluded that "[i]t was this which made [Shaw], in the language of the late Judge Curtis, the greatest magistrate which this country has produced.,

Shaw's mid-nineteenth century jurisprudential perspective is reflected in The Common Law as well as in Holmes's later work. Indeed, Holmes chose to open The Common Law with an attack on those who, like Christopher Columbus Langdell, the founder of the modern case method, disagreed with Shaw's conception of the judicial role. ${ }^{78}$ Contrary to

71. Holmes, supra note 10.

72. Id. at 467 .

73. See id.

74. The historian Daniel Boorstin has called Holmes "the Shaw of the early 20th century.” DANiEl J. BoORstin, The AMERICANS: The NATIONAl EXPERIENCE 42 (1965).

75. Oliver Wendell Holmes, JR., The Common LaW 72 (Am. Bar Ass'n 2009) (1881).

76. Id.

77. Id.

78. Id. at 1, 3-4. The opening paragraphs of The Common Law, as well as the attack on Langdell's views, can be traced to Holmes's unsigned 1880 book review of 
Langdell—and of course, the formalists of the subsequent Lochner eraHolmes argued that the common law could not be reduced to apolitical, logical postulates. Rather, the common law was the product of "[t]he felt necessities of the time, the prevalent moral and political theories, intuitions of public policy, avowed or unconscious, even the prejudices which judges share with their fellow-men." ${ }^{, 79}$ In shaping the common law, therefore, courts had reflected and should reflect "what is expedient for the community concerned." ${ }^{80}$

Although Holmes's concept of the judicial role resembled Shaw's, Holmes applied this concept in a different era. During the Lochner era, the judiciary was content with the status quo at a time when courts might have fashioned new responses to the problem of injuries caused by industrialization. In 1897, Holmes addressed the problem of industrial accidents in his classic essay, The Path of the Law. ${ }^{81}$ He first argued, as he had in The Common Law, that behind its form and logic, the common law reflects judicial accommodation of "competing legislative grounds." Accordingly, "the means do not exist for determinations that shall be good for all time, and ... the decision can do no more than embody the preference of a given body in a given time and place." 83 Thus, as social conditions and values change, the judge must reconsider the common law. Indeed, Holmes argued that "[w]e do not realize how large a part of our law is open to reconsideration upon a slight change in the habit of the public mind." 84

Turning specifically to the common law of worker injuries, Holmes developed themes that presage the enterprise liability theories of the Legal Realists three decades later. Holmes noted that judges instruct juries "that an employer is not liable to an employee for an injury received

Langdell's contracts casebook. See Book Notice, 14 AM. L. REV. 233, 233-35 (1880) (reviewing C.C. LANGDELl, A SELECTION OF CASES ON THE LAW OF CONTRACTS, WITH A SuMMARY OF THE TOPICS COVERED BY THE CASES (2d ed. 1879)).

79. HoLMES, supra note 75 , at 1.

80. Id. at 24 .

81. Holmes, supra note 10, at 467. The Path of the Law is an acknowledged classic in American legal and intellectual history. See, e.g., Morton G. White, Social Thought in AMERICA: The Revolt AgAinst Formalism 59-75 (1949).

82. Holmes, supra note 10, at 466. Mark Tushnet has suggested it would be a mistake to equate too closely Holmes's 1881 view of the role of policy in judicial lawmaking with his 1897 view. See Mark Tushnet, The Logic of Experience: Oliver Wendell Holmes on the Supreme Judicial Court, 63 VA. L. REV. 975, 1048-49 (1977).

83. Holmes, supra note 10 , at 466 .

84. Id. 
in the course of his employment unless he is negligent." ${ }^{85}$ Despite this instruction, juries "generally find for the plaintiff if the case is allowed to go to them." 86 Holmes asked why this discrepancy existed. His answer was that the common law was out of touch with popular perceptions of sound policy: "[T] confine liability to cases where a prudent man might have foreseen the injury, or at least the danger ...., ${ }^{87}$ In contrast, "the inclination of a very large part of the community is to make certain classes of persons insure the safety of those with whom they deal." 88

The explanation for this shift in policy preferences lay in the successful industrialization of America during the nineteenth century. In Holmes's view, traditional tort doctrine originated in preindustrial America - in "the old days of isolated, ungeneralized wrongs, assaults, slanders, and the like, where the damages might be taken to lie where they fell by legal judgment." ${ }^{\circ 9}$ In contrast, the torts of industrialized America "with which our courts are kept busy to-day are mainly the incidents of certain well known businesses. They are injuries to person or property by railroads, factories, and the like."90 With respect to these torts, the liability "is estimated, and sooner or later goes into the price paid by the public. The public really pays the damages."91 Accordingly, the "question of liability, if pressed far enough, is really the question how far it is desirable that the public should insure the safety of those whose work it uses."

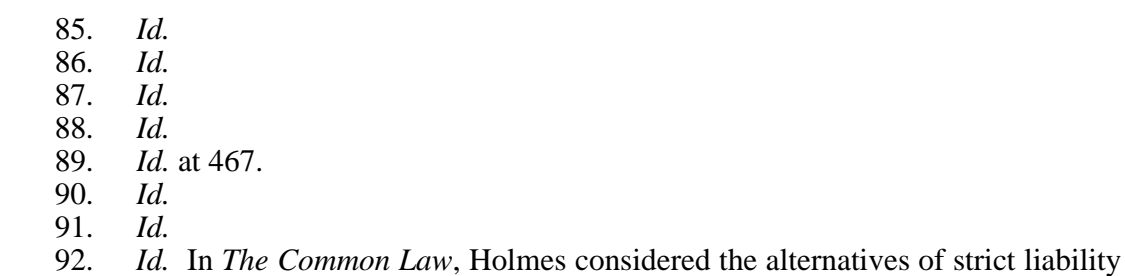
and social insurance. He wrote, "The state might conceivably make itself a mutual insurance company against accidents, and distribute the burden of its citizens' mishaps among all its members. There might be a pension for paralytics, and state aid for those who suffered in person or estate from tempest or wild beasts." HolmEs, supra note 75, at 65. Alternatively, "it might throw all loss upon the actor irrespective of fault." Id. Holmes rejected these alternatives as unsound:

The state does none of these things, however, and the prevailing view is that its cumbrous and expensive machinery ought not to be set in motion unless some clear benefit is to be derived from disturbing the status quo. State interference is an evil, where it cannot be shown to be a good.

Id. In his view, "[u]niversal insurance, if desired, can be better and more cheaply accomplished by private enterprise." Id. He also rejected the proposal to "redistribute losses simply on the ground that they resulted from the defendant's act." Id.

[Such an] undertaking ... would not only be open to [the above] objections, but ... to the still graver one of offending the sense of justice. Unless my act 
question and that this answer could lead to the rewriting of traditional tort law. Holmes wrote that "even now our theory upon this matter [the imposition of accident costs on employers] is open to reconsideration, although I am not prepared to say how I should decide if a reconsideration were proposed." 93

Holmes's recognition of the need for courts to reconsider traditional tort law and policy is consistent with his Lochner dissent's demand that courts not interfere with legislative attempts to cope with modern social and economic conditions and values. That dissent reflected Holmes's Darwinian view that legislation reflects the outcome of the struggle for survival of social policies - and his view that courts should, as Judge Posner puts it, "get out of the way of [that] struggle." 94 If courts were to rewrite the law of employee accidents, they would not be getting in the way by undoing what legislatures had done. Rather, they would be meeting what Holmes called "[t]he first requirement of a sound body of law[-] that it should correspond with the actual feelings and demands of the community, whether right or wrong." 95 Moreover, as Holmes pointed out in The Path of the Law, courts that were unwilling to consider reform of the

is of a nature to threaten others, unless under the circumstances a prudent man would have foreseen the possibility of harm, it is no more justifiable to make me indemnify my neighbor against the consequences, than to make me do the same thing if I had fallen upon him in a fit, or to compel me to insure him against lightning.

Id. As we have seen, however, popular attitudes changed over the next decades, and these considerations of justice were no longer as compelling.

93. See Holmes, supra note 10, at 466-67. If Holmes himself had addressed the substantive issue of what liability rule courts should adopt, he might have reached the conclusion that sound policy dictated that the status quo be retained. See Lamson v. Am. Ax \& Tool Co., 58 N.E. 585, 585-86 (Mass. 1900) (holding that assumption of risk bars worker's suit against employer); see also Balt. \& Ohio R.R. v. Goodman, 275 U.S. 66, 69-70 (1927) (finding that the driver of a truck struck while crossing a railroad was barred from recovery as a matter of law when the driver did not get out of his vehicle when he could not otherwise be sure a train was not dangerously near); United Zinc \& Chem. Co. v. Britt, 258 U.S. 268, 275-76 (1922) (holding that a child cannot recover when harmed by a poisonous pool of water when he was not induced to trespass by the pool but discovered it after he had come on the land). Judge Posner has written that "Holmes decided ... tort cases ... in accordance with the individualistic, anticollectivist—one might even say anti-socialist—philosophy that came naturally to him." Richard A. Posner, The Meaning of Judicial Self-Restraint, 59 IND. L.J. 1, 18 (1983).

94. Posner, supra note 3, at 527.

95. Id. (quoting HolmES, supra note 75, at 28) (internal quotation marks omitted). 
common law also were likely to succumb to the constitutional intervention characteristic of the Lochner era. ${ }^{96}$

In 1897, Holmes clearly foresaw the coming dominance of Lochnerstyle jurisprudence: "[P]eople who no longer hope to control the legislatures [now] look to the courts as expounders of the Constitutions ....,97 Moreover, "in some courts new principles have been discovered outside the bodies of those instruments, which may be generalized into acceptance of the economic doctrines which prevailed about fifty years ago, and wholesale prohibition of what a tribunal of lawyers does not think about [correctly]."98 Holmes's criticism of the judges of this era was that they "failed adequately to recognize their duty of weighing considerations of social advantage." 99 Recognition of this duty would lead to continual judicial reform of the common law. Furthermore, the dangers of Lochner arose from the failure to recognize this duty because the "duty is inevitable, and the result of the often proclaimed judicial aversion to deal with such considerations is simply to leave the very ground and foundation of judgments inarticulate, and often unconscious.”100 Holmes's hope was that if lawyers would "habitually ... consider more definitely and explicitly the social advantage on which the rule they lay down must be justified, they sometimes would hesitate where now they are confident, and see that really they were taking sides upon debatable and often burning questions." 101 Only a rejection of formalism and an explicit recognition of the role of policy in judicial lawmaking would lead both to reform of the common law and to restraint in judicial review of legislative attempts to adapt the legal system to twentieth-century conditions and values. ${ }^{102}$

\section{B. The Path Not Followed}

The failure of Lochner-era courts to follow Holmes's suggestions is not surprising. What is surprising and of great significance is that even progressive or liberal critics of the Lochner Court ignored Holmes's argument for a judicial role in the reform of the common law. Scholars, even those critical of Lochner, ignored or explicitly rejected the reform role that Shaw and Holmes urged for courts.

96. See Holmes, supra note 10, at 467-68.

97. Id. Holmes noted that a fear of socialism both infected "the comfortable classes of the community" and, he suspected, "influenced judicial action both here and in England,” although not necessarily consciously. Id. at 467.

98. Id. at 468.

99. Id. at 467 .

100. Id.

101. Id. at 468 .

102. Id. at $467-68$. 
This denial of an active reform role for courts would more or less freeze the common law as it stood at the turn of the century-permeated with nineteenth-century values. The Lochner Court, of course, would regard this ossification of the common law as ideal. Paradoxically, the revulsion of the Lochner critics at that Court's abuse of power in striking down legislative reforms explains in large part why these critics would argue for a judicial role that would preclude much-needed judicial reform of the common law. Lochner cast a pall over the idea of courts as agents of reform and spawned a view of the judicial role at odds with the view of judicial lawmaking articulated by Shaw and Holmes. In this period, we see the antecedents of what was to become the legal process scholarship of the 1950s and 1960s - a restrictive view of the common law role of courts that came to dominate American legal scholarship in the period after World War II.

A prominent example of this departure from the Holmesian reform orientation is Roscoe Pound. Pound was a progressive critic of the Lochner Court and an admirer of Holmes. ${ }^{103}$ In his 1908 article, Common Law and Legislation, Pound discussed both the constitutional and the common law roles of courts. ${ }^{104}$ He first took note of the substantial "output of legislation in all our jurisdictions and the indifference, if not contempt, with which that output is regarded by courts and lawyers." ${ }^{105}$ Pound wrote that courts during this era both struck down social legislation as unconstitutional and narrowly interpreted legislation that was not invalidated. ${ }^{106}$ In either event, the effect was to "impede or thwart social legislation demanded by ... industrial conditions." ${ }^{107}$ Pound argued for a more liberal judicial attitude toward social legislation and thus for a repudiation of the Lochner Court's posture. ${ }^{108}$

Pound sharply departed from Holmes, however, when he addressed the general role of courts. In Pound's scholarship, one does not find Holmes's call for the judiciary to bring the common law in touch with the dominant values of twentieth-century America. Instead, Pound argued for a limited conception of the judicial lawmaking power. He wrote that "[a]s the

103. See supra notes $67-70$ and accompanying text.

104. Roscoe Pound, Common Law and Legislation, 21 HARV. L. Rev. 383, 383407 (1908).

105. Id. at 383.

106. Id. at 385; see also Ives v. S. Buffalo Ry. Co., 94 N.E. 431, 448 (N.Y. 1911)

(holding unconstitutional New York's workers' compensation legislation).

107. Pound, supra note 104, at 385.

108. See id. 
development of law goes on, the function of the judge is confined within ever narrowing limits; the main source of modifications in legal relation comes to be more and more exclusively the legislature."109 Pound outlined both competence and political accountability arguments for limiting the judicial role, much as legal process scholars would do decades later. On the subject of competence, Pound wrote that "courts are less and less competent to formulate rules for new relations which require regulation. They have the experience of the past. But they do not have the facts of the present."110 Moreover, courts

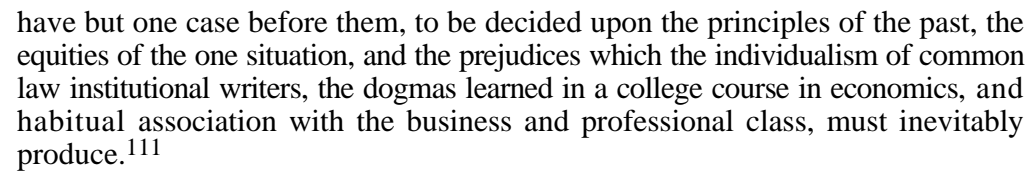
equities of the one situation, and the prejudices which the individualism of common law institutional writers, the dogmas learned in a college course in economics, and habitual association with the business and professional class, must inevitably produce. ${ }^{111}$

Not surprisingly, Pound would have restricted the lawmaking power of this incompetent and biased judiciary. "It is a sound instinct in the community," he wrote, "that objects to the settlement of questions of the highest social import in private litigations between John Doe and Richard Roe."112

In addition, the nondemocratic nature of judicial lawmaking reinforced Pound's pessimistic view of the courts: "We recognize that legislation is the more truly democratic form of law-making. We see in legislation the more direct and accurate expression of the general will."113 Moreover, Pound continued, "[w]e are told that law-making of the future will consist in putting the sanction of society on what has been worked out in the sociological laboratory. That courts cannot conduct such laboratories is self evident."114 Indeed, "[c]ourts are fond of saying that they apply old principles to new situations. But at times they must apply new principles to situations both old and new. ... The old principles are in common law."115

Pound drew a broad institutional lesson from an era of "judicial obstruction or nullification of the social policies to which more and more [of the public] is compelled to be committed.”116 Pound did not stop with a demand that courts restrain themselves in their exercise of the

109. Id. at 403 n.2 (quoting HenRy Sidgwick, THE ElEMENTs of Politics 203 (2d ed. 1897)) (internal quotation marks omitted).

110. Id. at 403.

111. Id. at 403-04.

112. Id. at 404 .

113. Id. at 406 (citing Bernard Bosanquet, The Philosophical TheORY of the STATE 120-23 (1899)).

114. Id. (footnote omitted).

115. Id. at 406-07 (footnote omitted).

116. Id. at 407. 
power of judicial review. Rather, he generalized beyond constitutional law. He saw courts as incompetent and undemocratic, and he sought to confine their lawmaking role within "ever narrowing limits."117 Major revisions of the law-including the common law-were to be left to the legislatures. Rather than urge, as Holmes had, that the courts themselves revise the common law to reflect the emerging political philosophy of a new era, Pound gave up on the courts as a major lawmaking institution. ${ }^{118}$

Pound's position is understandable as a consequence of his revulsion at the activities of courts of his era. In this vein, Louis Jaffe later wrote, "When I was a student in the Harvard Law School in 1928 and 1931, I came to believe that the judiciary by its very nature was at the worst reactionary and at the least undependable." 119 The cause of this belief, of course, was Lochner and its progeny. "This was a time when the courts were declaring social legislation unconstitutional, were stifling union organization by injunction, and more or less generally throwing their weight behind big business and finance." ${ }^{120}$ The extent of distrust of judicial power is illustrated by the questionable status of even Marbury $v$. Madison $^{121}$ among Harvard law students of that era. "Led by Frankfurter," Jaffe wrote, "we were all passionate believers in the dogma of judicial restraint. Some of us indeed were sympathetic to the argument that John Marshall's assertion in Marbury v. Madison of the power to declare legislation unconstitutional was 'usurpation.","122

In this context, Pound's position that judicial lawmaking should be confined within ever narrowing limits is understandable. Nonetheless, his thesis is hardly an immutable institutional truth. ${ }^{123}$ More importantly, his position conflicts with the teachings of Shaw and Holmes. A restrictive view of judicial creativity overlooks the reality that judicial alteration of

117. Id. at 403 n.2 (quoting SIDGWICK, supra note 109, at 203) (internal quotation marks omitted).

118. See id. at 403; Pound, supra note 28, at 622. However, at times, Pound envisioned what appears to be a more creative role for the judiciary. See, e.g., Pound, Judicial Decision, supra note 67 , at $641,802,940$. Nevertheless, the themes of limited judicial competence and accountability and the desire to restrict judicial lawmaking persisted in his writings throughout his life. See, e.g., Roscoe Pound, An InTROduction to the Philosophy of LAW 102-03 (1922).

119. LOUIS L. JAFFE, ENGLISH AND AMERICAN JUDGES AS LAWMAKERS 85 (1969).

120. Id.

121. 5 U.S. (1 Cranch) 137 (1803).

122. JAFFE, supra note 119, at 86 (footnote omitted).

123. See Duncan Kennedy, Form and Substance in Private Law Adjudication, 89 HARV. L. REV. 1685, 1756 (1976). 
the common law is always subject to legislative reversal. In addition, this view would leave America with a common law reflective of nineteenth-century values unless legislatures were mobilized-an unlikely prospect given the general inattention of legislatures to the common law in all but crisis situations. ${ }^{124}$

\section{THE INDUSTRIAL ACCIDENT CRISIS, THE WORKERS' COMPENSATION SOLUTION, AND A CONSTITUTIONAL CONFRONTATION}

\section{A. The Industrial Accident Crisis and the Workers' Compensation Solution}

Faced with the unprecedented crisis in workplace accidents-with its toll of uncompensated widows, orphans, and injured workers-American legislatures were mobilized. In his 1907 speech, President Theodore Roosevelt responded to this "bitter injustice" by proposing what we now know as workers' compensation. Workers, Roosevelt said, "should receive ... a certain definite and limited compensation for all accidents ... as an incident of the performance of their duties.”125 Enactment of such legislation, Roosevelt argued, would not only induce greater safety but would be a "step toward the goal of securing, so far as human wisdom can secure, fair and equitable treatment for every one of our people."126 "Employers would 'gain a desirable certainty of obligation' and 'get rid of' burdensome and costly litigation, while the 'workman and the workman's family would be relieved from a crushing load.",127 In short, Roosevelt argued, "from every standpoint, the change would be a benefit."

124. One early attempt to achieve legislative change in the significant area of automobile accidents occurred in the 1930s. See generally ColumBIA UNIV. CounCIL FOR RESEARCH IN THE SOC. SCIS., REPORT BY THE COMMITTEE TO STUDY COMPENSATION FOR AUTOMOBILE ACCIDENTS (1932) (recognizing the "problem of compensation for injuries caused by" motor vehicle accidents and "presenting an unbiased statement of ... findings, and suggestions for the solutions of the problems involved" (footnote omitted)). The modern movement toward no-fault auto compensation plans gained great impetus from Robert Keeton and Jeffrey O’Connell's work in the 1960s. See, e.g., RoBERT E. KeEton \& JefFrey O’CONNEll, Basic Protection for the TrafFic Victim: A Blueprint FOR REFORMING AUTOMOBILE INSURANCE 124-89 (1965).

125. WITT, supra note 4, at 3 (quoting Proud of His Georgian Ancestry, supra note 56, at 11) (internal quotation marks omitted).

126. Id. at 4 (quoting Proud of His Georgian Ancestry, supra note 56, at 11) (internal quotation marks omitted).

127. Id. (quoting Proud of His Georgian Ancestry, supra note 56, at 11).

128. Id. (quoting Proud of His Georgian Ancestry, supra note 56, at 11) (internal quotation marks omitted). 
Following Roosevelt's lead, New York enacted the nation's first workers' compensation statute in 1910. ${ }^{129}$ Between 1910 and 1920, state after state enacted workers' compensation legislation. ${ }^{130}$ Broadly outlined, this legislation ensured that persons injured in the course of employment were assured compensation even though their injuries could not be linked to negligence or fault. ${ }^{131}$ The trade-off for this assurance of compensation was that the compensation would be limited. ${ }^{132}$

The enactment of this legislation marked a seminal moment not only in American accident law, but also in America's commitment to assure the economic security of its citizens. Indeed, decades later "ideas drawn from accident-law reform powerfully influenced New Deal policymaking," as "social reformers ... advocate[d] social insurance programs organized around workmen's compensation principles." "33 In fact, "[t]races of the workmen's compensation model underlay the views of [Franklin] Roosevelt himself." "134 In creating the committee that would "craft what would become the Social Security Act of 1935," for example, Roosevelt "drew on the basic lessons of workmen's compensation." 135 The goal "was to safeguard individual wage earners and their families against those 'misfortunes which cannot be wholly eliminated in this man-made world of ours.",136 “Securing the wage earner and his family against the 'hazards and vicissitudes' of modern wage earning became one of the central themes of [Franklin] Roosevelt's presidency, and a core metaphor in his campaign was the work accident and the experience of workmen's compensation."137 And, as we will see, a similar impulse lay behind the seminal enterprise liability analyses of Leon Green and Karl Llewellyn in the late 1920s and early 1930s.

129. See N.Y. Cent. R.R. v. White, 243 U.S. 188, 192-95 (1917)

130. See Friedman \& Ladinsky, supra note 14, at 70.

131. Id.

132. Id. at 71.

133. WITT, supra note 4, at 199.

134. Id.

135. Id.

136. Id.

137. Id. 


\title{
B. A "Revolutionary" Solution Collides with Lochner-Style Jurisprudence
}

But that is looking to the future. In the short run, the nation's first workers' compensation legislation ran headlong into the jurisprudence of the Lochner era. Less than a year after New York enacted its seminal legislation, the New York Court of Appeals, in Ives v. South Buffalo Railway Co., held in 1911 that the legislative scheme violated the due process clauses of both the federal and state constitutions. ${ }^{138}$ The court conceded that the legislation was supported by "attractive and desirable" "economic, philosophical, and moral theories," as well as statistical tables. ${ }^{139}$ And it purported to find merit in the finding of the commission that recommended the plan that "our system of dealing with industrial accidents is economically, morally, and legally unsound."140 Nevertheless, the court wrote that such considerations were "subordinate to the primary question whether [the plan] ... infring[es] upon the letter or spirit of our written Constitutions." 141 In the court's view, this "radical ... legislation" was "plainly revolutionary.", If2 If, the court wrote, the "economic and sociologic arguments ... advanced in support of this statute can be allowed to subvert the fundamental idea of property, then there is no private right entirely safe."143

\begin{abstract}
If the Legislature can say to an employer, "You must compensate your employ[ee] for an injury not caused by you or by your fault," why can it not go further and say to the man of wealth, "You have more property than you need, and your neighbor is so poor that he can barely subsist; in the interest of natural justice you must divide with your neighbor, so that he and his dependents shall not become a charge upon the state"?144
\end{abstract}

The Ives court concluded, the "final and simple analysis [is] that [it] is taking the property of A. and giving it to B., and that cannot be done under our Constitutions.”, 145

The Ives decision unleashed public wrath and "a storm of disapproval," causing, along with the Supreme Court's Lochner decision, "the greatest court controversy since Dred Scott."146 Indeed, Theodore Roosevelt argued that "Dred Scott was worse in degree, but not in kind" than Ives, which, he asserted, was "a most flagrant and wanton abuse of a great

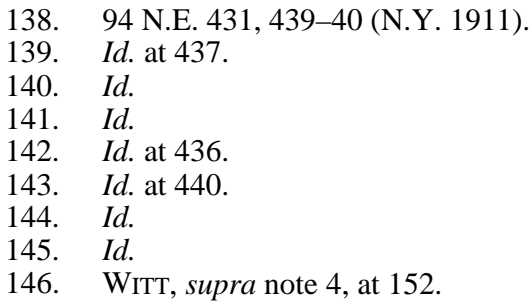


power.”147 Ives became a centerpiece in Roosevelt's campaign for the recall of judicial decisions. ${ }^{148}$

The voters of New York essentially did recall Ives, enacting a constitutional amendment in 1913 authorizing the state legislature to enact workers' compensation legislation, which the legislature promptly did. ${ }^{149}$ Meanwhile, Cardozo had been appointed to the Court of Appeals in 1913 and sat on that court as it upheld, with Cardozo concurring, the new legislation in Jensen v. Southern Pacific Co. in $1915 .{ }^{150}$ The Jensen holding overruled Ives by finding that the new legislation did not violate the Federal Constitution. ${ }^{151}$

\section{MACPHERSON V. BUICK AND THE JUDICIAL REFORM OF THE COMMON LAW}

The enactment of workers' compensation legislation was a landmark event in twentieth-century personal injury law. For Legal Realists like Leon Green, it would be the inspiration for further reforms-legislative or judicial—of tort law to reflect twentieth-century values. A second landmark event - and an early instance of judicial reform-came one year after Jensen with Justice Cardozo's 1916 decision in MacPherson v. Buick Motor Co. ${ }^{152}$ Prior to MacPherson, a person injured by a negligently manufactured product had no tort action against the manufacturer if, as was most often the case, the product had been purchased from a dealer, as opposed to the manufacturer. ${ }^{153}$ Privity of contract was required for a tort action. ${ }^{154}$ An exception to this privity requirement had been established, however, for products that were imminently dangerous to life or health. ${ }^{155}$ In MacPherson, the imminently dangerous exception was so expansively interpreted that by the end of the opinion it was on its way to becoming the rule for all products. ${ }^{156}$ As Judge Posner has observed, MacPherson was Cardozo's "most important decision in terms of impact on the law,"

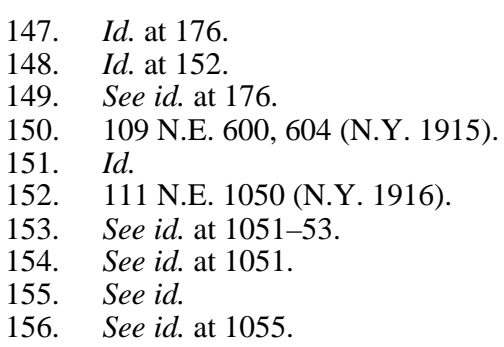


as other state supreme courts would follow Cardozo's lead in eliminating the privity barrier to negligence actions against manufacturers. ${ }^{157}$

\section{CARDOZO’s PRAGMATIC JURISPRUDENCE}

\section{A. Cardozo on Judicial Lawmaking}

MacPherson notwithstanding, a formalist view of the judicial lawmaking role dominated the judicial opinions and scholarship of the first half of the twentieth century, supplemented with the views of those like Pound, who rejected formalism but nevertheless held a cramped view of judicial lawmaking. As courts and scholars moved away from the creativity urged by Shaw and Holmes, they often simply ignored, and at times explicitly rejected, a significant reform role for the courts with regard to common law subjects. This may have been the dominant view during the early part of the century, but it was not the view of Cardozo who carried on the Holmesian tradition in his extrajudicial writings, most notably in his classic 1921 book, The Nature of the Judicial Process.

\section{B. The Role of Logic, History, and Custom}

Cardozo rejected formalism, writing in The Nature of the Judicial Process that "[t]he common law does not work from pre-established truths of universal and inflexible validity to conclusions derived from them deductively." 158 Instead, "[i]ts method is inductive, and it draws its generalizations from particulars." "159 Moreover, "[t]he rules and principles of case law have never been treated as final truths, but as working hypotheses, continually retested in those great laboratories of the law, the courts of justice." 160 Indeed, "[n]othing is stable. Nothing absolute. All is fluid and changeable. There is an endless 'becoming."”'161

"In this perpetual flux," Cardozo wrote, a judge must first "extract from the precedents the underlying principle, the ratio decidendi." ${ }^{162}$ Then the judge must "determine the path or direction along which the principle is to move and develop."163 Cardozo listed four methods for determining that path or direction. First, "[t]he directive force of a principle may be

157. See Posner, supra note 19 , at 109.

158. CARDOZO, supra note 23, at 22-23.

159. Id. at 23 .

160. Id. (quoting Munroe Smith, Jurisprudence 21 (1908)) (internal quotation marks omitted).

161. Id. at 28.

162. Id.

163. Id. 
exerted along the line of logical progression."164 Cardozo called this "the method of philosophy."165 Although some had "spoken as if the principle of ... logical development ... meant little or nothing in our law," Cardozo rejected this view, writing "[l]ogical consistency does not cease to be a good because it is not the supreme good."166 "We must know where logic and philosophy lead even though we may determine to abandon them for other guides."

Cardozo pointed out, moreover, that logical development from precedent does not always lead to a single conclusion. At some point, competing lines of precedent come into play and point to different paths. At that point, "we must make a choice between them."168 In such cases a second method, the method of history, may "give direction to development." The history of a doctrine may also suggest limits to its logical extension. ${ }^{170}$ Even where the claims of "the directive force of history ... are most assertive," however, they do not "confine[] the law of the future to uninspired repetition of the law of the present and the past.,"171 "Very often, the effect of history is to make the path of logic clear." ${ }^{172}$ In other words, "history, in illuminating the past, illuminates the present, and in illuminating the present, illuminates the future."

164. Id. at 30 .

165. Id. Cardozo placed method of philosophy first, not because it was the most important but

because it has ... a certain presumption in its favor. Given a mass of particulars, a congeries of judgments on related topics, the principle that unifies and rationalizes them has a tendency, and a legitimate one, to project and extend itself to new cases within the limits of its capacity to unify and rationalize. It has the primacy that comes from natural and orderly and logical succession.

Id. at 31 .

166. Id. at 32 .

167. Id. at 38.

168. Id. at 43.

169. Id. at 65 . Cardozo wrote that "[s]ome conceptions of the law owe their existing form almost exclusively to history.” Id. at 52 . The law of real property provides an apt example. Id. at 54. "Never by a process of logical deduction from the idea of abstract ownership could we distinguish the incidents of an estate in fee simple from those of an estate for life, or those of an estate for life from those of an estate for years." Id.

170. Id. at 51. "The tendency of a principle to expand itself to the limit of its logic may be counteracted by the tendency to confine itself within the limits of its history." Id.

171. Id. at 53.

172. Id. at 51.

173. Id. at 53. 
"If history and philosophy do not serve to fix the direction of a principle," Cardozo's third method might: “[C]ustom may step in."174 Although in the past law had been seen as an articulation of customary practices, Cardozo wrote that the effect of custom "in the development of common law is less today."175 Today, "we look to custom, not so much for the creation of new rules, but for the tests and standards that are to determine how established rules shall be applied," ${ }^{176}$ as a guide, for example, in determining whether due care has been exercised. ${ }^{177}$

\section{Cardozo's Legal Pragmatism}

None of this would have been startling or upsetting to lawyers and judges in Cardozo's day. However, Cardozo then turned to the fourth method. And here his jurisprudence becomes more interesting - and Holmesian. In a nutshell, Cardozo's view was that judges are lawmakers and social policy - the welfare of society — plays a role in their lawmaking. At times, Cardozo wrote, "we must bend symmetry, ignore history and sacrifice custom in the pursuit of other and larger ends." moved from history, philosophy, and custom "to the force which in our day and generation is becoming the greatest of them all, the power of social justice which finds its outlet and expression in the method of sociology." 179 By this Cardozo simply meant that "[t]he final cause of law is the welfare of society." replace "the demon of formalism [that] tempts the intellect with the lure of scientific order."181 "[I]n every department of the law . . . the social value of a rule has become a test of growing power and importance."

174. Id. at 58 .

175. Id. at 59. Blackstone had suggested that the common law, or at least some of it, was indistinguishable from, or simply an articulation of, customary practices. Id. (quoting William BlacKSTONe, COMMENTARIES 67 (Dawsons of Pall Mall 1st ed. 1966)).

176. Id. at 60 .

177. Id. at 63.

178. Id. at 65 .

179. Id. at $65-66$.

180. Id. at 66. Cardozo was aware that "[s]ocial welfare is a broad term." Id. at 71. "It may mean ... public policy, the good of the collective body. In such cases, its demands are often those of mere expediency or prudence." Id. at 72. On the other hand, "[i]t may mean ... the social gain that is wrought by adherence to the standards of right conduct, which find expression in the mores of the community. In such cases, its demands are those of religion or of ethics or of the social sense of justice ...." Id. The term social welfare "if not precise enough for the philosopher, will at least be found sufficiently definite and inclusive to suit the purposes of the judge.” Id. at 73.

181. Id. at 66.

182. Id. at 73. 
Cardozo was quick to assure the reader, however, "that judges are [not] commissioned to set aside existing rules at pleasure in favor of any other set of rules which they may hold to be expedient or wise."183 Indeed, it is only when judges "are called upon to say how far existing rules are to be extended or restricted [that judges] must let the welfare of society fix the path, its direction and its distance."184 Quoting one of Holmes’s “flashing epigrams," Cardozo wrote, "I recognize without hesitation that judges must and do legislate, but they do so only interstitially; they are confined from molar to molecular motions." 185 Cardozo concluded, still quoting Holmes, a "common-law judge could not say, I think the doctrine of consideration a bit of historical nonsense and shall not enforce it in my court."

Whatever might be meant by "interstitial," Cardozo was clear that the "function of our courts [is] ... to keep the doctrines up to date with the mores by continual restatement and by giving them a continually new content."187 The judge must innovate, Cardozo informed the reader, "for with new conditions there must be new rules."188 In short, "[t]his means ... that the juristic philosophy of the common law is at bottom the philosophy of pragmatism." 189 Moreover, this method is not new. "It is the method by which the common law has renewed its life at the hands of its great masters - the method of Mansfield and Marshall and Kent and Holmes."190

To illustrate the workings of the method of sociology, Cardozo focused on "fields in which the method is in antagonism to other[ methods]."191 Private law provided examples of this antagonism, and Cardozo wrote that private law is a "field where the dominance of the method of

183. Id. at $66-67$.

184. Id. at 67.

185. Id. at 69 (quoting S. Pac. Co. v. Jensen, 244 U.S. 205, 221 (1917) (Holmes, J., dissenting)) (internal quotation marks omitted).

186. Id. (quoting Jensen, 244 U.S. at 221 (Holmes, J., dissenting)) (internal quotation marks omitted).

187. Id. at 135 (quoting Corbin, supra note 26, at 771) (internal quotation marks omitted).

188. Id. at 137.

189. Id. at 102 (citing Pound, supra note 28, at 609). "By emphasizing standards of utility, by setting up the adaptation to an end as a test and evidence of verity, pragmatism is profoundly affecting the development of juristic thought.” BENJAMIN N. CARDOZO, THE GROWTH OF THE LAW 127 (1924).

190. CARDOZO, supra note 23, at 137-38.

191. Id. at 75 . 
sociology may be reckoned as assured." ${ }^{\text {,92 }}$ Indeed, "some rules of private law ... have been shaped in their creation by public policy and this, not merely silently or in conjunction with other forces, but avowedly and almost, if not quite, exclusively."193 "[P]ublic policy, as determined by new conditions, is competent to change" such common law rules. ${ }^{194}$

As an example of this process, Cardozo examined "modern decisions [that] liberalized the common law rule condemning contracts in restraint of trade. The courts have here allowed themselves a freedom of action which in many branches of the law they might be reluctant to avow."195 Cardozo approvingly quoted a Massachusetts decision in which the judge wrote, "[a]rbitrary rules which were originally well founded have thus been made to yield to changed conditions, and underlying principles are applied to existing methods of doing business. The tendencies in most of the American courts are in the same direction.”196

Another example offered by Cardozo was the judge-made law concerning the activities of labor unions. Here, Cardozo wrote, "[t]he suspicion and even hostility of an earlier generation found reflection in judicial decisions which a changing conception of social values ... made it necessary to recast."197 Cardozo saw this as a field in which "the law is yet in the making or better perhaps in the remaking. We cannot doubt that its new form will bear an impress of social needs and values which are emerging even now to recognition and to power."198

Exceeding such common law decisions in importance, however, were the constitutional decisions of the Lochner-era. And here the method of sociology also loomed large. During the nineteenth century, Cardozo wrote, "[l]aissez faire was not only a counsel of caution which statesmen would do well to heed. It was a categorical imperative which statesmen, as well as judges, must obey."199 It was "one of [those] eternal legal conceptions involved in the very idea of justice and containing potentially an exact rule for every case to be reached by an absolute process of logical deduction."200

By the end of the century, however, a new political philosophy was emerging in this country, and Cardozo quoted Dicey's description of

192. Id. at 94.

193. Id.

194. Id.

195. Id. at $94-95$.

196. Id. at 96 (quoting Anchor Elec. Co. v. Hawkes, 50 N.E. 509, 511 (Mass. 1898)).

197. Id. at 96-97.

198. Id. at 97.

199. Id. at 77.

200. Id. at 77-78 (quoting Roscoe Pound, Juristic Science and Law, 31 HARV. L. REV. 1047, 1048 (1918)) (internal quotation marks omitted). 
similar development in England where "'movement from individualistic liberalism to unsystematic collectivism' had brought changes in the social order which carried with them the need of a new formulation of fundamental rights and duties."201 In America, however, "[c]ourts still spoke in the phrases of a philosophy that had served its day."202 "Even as late as 1905, the decision in Lochner v. N.Y. . . still spoke in terms untouched by the light of the new spirit." ${ }^{\text {,203 }}$ That new spirit, however, was famously articulated by Holmes in his Lochner dissent. It was Holmes's dissent, Cardozo wrote, "which men will turn to in the future as the beginning of an era." ${ }^{204}$ In Cardozo's view, Holmes's Lochner dissent represented "a new conception of the significance of constitutional limitations in the domain of individual liberty,"205 and Cardozo reportedalthough with mistaken optimism as it turned out-that it was this "conception of liberty which is dominant today."206

Turning to an example from his own court, Cardozo wrote that "[c]ourts have often been led into error in passing upon the validity of a statute, not from misunderstanding of the law, but from misunderstanding of the facts.”207 In 1907 the New York Court of Appeals had held a statute forbidding night work by women unconstitutional. ${ }^{208}$ "In 1915, [however,] with fuller knowledge of the investigations of social workers, a like statute was held to be reasonable and valid."209 For Cardozo, this episode revealed that "today ... statutes are to be viewed, not ... as pronouncements of abstract principles for the guidance of an ideal community, but in the setting ... of present-day conditions, as revealed by the labors of economists and students of the social sciences in our own country and abroad."210

201. See id. at 78 .

202. Id.

203. Id. at 79 (citation omitted).

204. Id.

205. Id. at 78 .

206. Id. at 80 .

207. Id. at 80-81.

208. People v. Williams, 81 N.E. 778, 780 (N.Y. 1907).

209. CARDOZO, supra note 23, at 81 (citing People v. Schweinler Press, 108 N.E. 639 (N.Y. 1915)).

210. Id. 


\section{Cardozo's Reticent Jurisprudence: MacPherson and Ives/Jensen Revisited}

Cardozo's The Nature of the Judicial Process is indeed an eloquent exposition of the pragmatic jurisprudence that Holmes had introduced two decades earlier in The Path of the Law. But it is incomplete as an account of jurisprudential events that occurred during the intervening two decades. Absent from Cardozo's analysis is an extended discussion both of his own decision in MacPherson v. Buick and of the tumultuous events leading to the first workers' compensation legislation in the nation. These developments provide far better illustrations of the jurisprudential phenomena Cardozo discussed than the examples Cardozo chose to analyze. These developments also provide an important link to the work of the Legal Realists Leon Green and Karl Llewellyn, to which we will turn shortly.

Judge Posner writes that Cardozo’s MacPherson opinion was “[c]arefully qualified ... [and] modest ... in pretending to be restating rather than changing the law of New York, [and] reticent ... about the policy considerations relevant to the change it made." 211 "Yet . . . it is the very caution, modesty, and reticence of the opinion that explain its rapid adoption by other states. MacPherson is the quietest of revolutionary manifestos, the least unsettling to conservative professional sensibilities,"212 even as it "inaugurated fundamental changes in American tort law."213

Cardozo displayed similar reticence when it came to discussing MacPherson in his extrajudicial writings. Today law students are taught to see MacPherson as the quintessential example of an exception to a legal rule "swallowing" the original rule and replacing it. Cardozo did discuss the phenomenon of an exception to a legal doctrine growing over time to become the new doctrine, but he did not mention MacPherson. Instead, cases dealing with the right of a beneficiary to recover on a contract provided Cardozo with "a striking illustration of the force of logical consistency, then of its gradual breaking down before the demands of practical convenience in isolated or exceptional instances, and finally of the generative force of the exceptions as a new stock."214 MacPherson, however, would have provided a far more striking - and well-knownexample of an exception to a legal rule swallowing the rule. Indeed,

211. Posner, supra note 19, at 109; see also KAUFMAN, supra note 30, at 273 ("Cardozo gave only glancing intimations that any policy consideration affected his views of the proper outcome in MacPherson.... Cardozo presented the new rule in the most modest terms.").

212. POSNER, supra note 19, at 109.

213. Id. at 42.

214. CARDOZO, supra note 23, at 99. 
MacPherson is the classic case of what Cardozo described as "[r]ules derived by a process of logical deduction ... [breaking] down before the slow and steady and erosive action of utility and justice.”215

Moreover, Cardozo might have used MacPherson as a prime example of the method of sociology, which counsels that it is the "function of our courts ... to keep the doctrines up to date with the mores by continual restatement and by giving them a continually new content." ${ }^{, 216}$ And MacPherson could have been an example of a time when "we must bend symmetry, ignore history and sacrifice custom in the pursuit of other and larger ends." 217 It was also a reminder that "in every department of law ... the social value of a rule has become a test of growing power and importance."218

So why did Cardozo not write of MacPherson as an example of an exception to a rule swallowing the rule, of courts keeping legal doctrine up to date with the changing mores of society? For one thing, in that age of legal formalism, Cardozo might have feared that his book was already controversial enough. ${ }^{219}$ Moreover, to write of MacPherson in that manner would have left him open to the charge that he had only pretended to restate the law in MacPherson-in other words, that he had deceived his judicial colleagues. Cardozo would have been loath to make an admission that would have opened him to the charge of dishonesty. Beyond this, it would have made it more difficult to convince his colleagues in future cases that he was merely "restating" the law, even in cases where that was, in fact, the case. Moreover, it might have caused other courtsloath to confess to lawmaking - to avoid following MacPherson's lead. But beyond all that, there is Cardozo's apparent modesty, for he did not discuss MacPherson even in contexts in which such a discussion might have helped to persuade other courts to follow it.

\footnotetext{
215. Id. at $99-100$.

216. Id. at 135 (quoting Corbin, supra note 26, at 771) (internal quotation marks omitted).

217. Id. at 65.

218. Id. at 73 .

219. When first asked to allow his Yale lectures to be published as a book, Cardozo balked, saying that he did "not dare to have [them] published" lest he "be impeached." Corbin, supra note 23, at 198 . Although upon publication the book was praised by the likes of Learned Hand and Harlan Fiske Stone, Hand wrote that there would be "excellent people who cannot help feeling that the voice of [the] book is in a way the voice of heresy.” Learned Hand, Book Review, 35 HARV. L. REV. 479, 480 (1922) (reviewing CARDOZO, supra note 23).
} 
Indeed, Cardozo seems to have gone out of his way not to discuss MacPherson by name. By the date that Cardozo gave his lectures, the persuasiveness of Cardozo's MacPherson decision had become evident. Cardozo, in fact, discussed a Second Circuit decision that had relied on MacPherson in deciding to reverse its own position in a previous decision in the same case. ${ }^{220}$ But he did not mention MacPherson by name in the text. ${ }^{221}$ Rather than noting the federal court's decision as evidence of a tendency of courts to follow MacPherson, Cardozo characterized the sequence of federal decisions as an "extreme illustration" of the ability of American courts to "overrule their own prior decisions when manifestly erroneous."222

If the Second Circuit decision was an extreme example of overruling, the New York Court of Appeals' 1915 Jensen decision upholding the reenacted workers' compensation legislation, and overruling the 1911 Ives decision by holding that the new legislation did not violate the Federal Constitution, was a monumental overruling. It will be recalled that during the decade preceding The Nature of the Judicial Process, New York had been through a legislative and judicial firestorm stirred up by Ives. ${ }^{223}$ As he did in the case of MacPherson, Cardozo chose to steer clear of these momentous events, choosing the previously discussed, closely parallel—but far less controversial—women's night work decisions as an example of the Court of Appeals overruling its previous Lochnerlike decisions. ${ }^{224}$ Cardozo wrote that in initially invalidating the women's

220. See CARDOZO, supra note 23, at 158-59 (discussing Johnson v. Cadillac Motor Car Co., 261 F. 878 (2d Cir. 1919)). In Johnson, the plaintiff sued the manufacturer of a defective car and prevailed in the trial court, but the Second Circuit reversed on the ground that the plaintiff was not in privity of contract with the manufacturer. $261 \mathrm{~F}$. at 878-79. The trial court then dismissed the suit based on that ruling. Id. at 879. This time the plaintiff appealed. See id. at 882. In the meantime, the Court of Appeals had decided MacPherson. Id. On the Johnson plaintiff's appeal, the Second Circuit court, relying on MacPherson, overruled its prior ruling and reversed the dismissal. Id. at 88287.

221. See CARDOZO, supra note 23, at 159. However, Cardozo did discuss MacPherson in the text of The Growth of the Law. CARDOzO, supra note 189. There he observed that the law before MacPherson was equivocal. Id. at 41 . He also wrote that the struggle between logic and utility persisted in courts dealing with the privity requirement, noting that the law in the United States was "not uniform." Id. at 78.

222. CARDOZO, supra note 23, at 158-59.

223. See supra notes $15-18$ and accompanying text.

224. How far clear can be seen in Cardozo's discussion of Holmes's essay, The Path of the Law, which preceded Roosevelt's rousing 1907 call to action by a decade. In The Nature of the Judicial Process, Cardozo quoted a large block of material in which Holmes argued, "[w]e do not realize how large a part of our law is open to reconsideration upon a slight change in the habit of the public mind.” Holmes, supra note 10, at 466; see also CARDOzo, supra note 23, at 117-18 (quoting Holmes, supra note 10, at 466). However, Cardozo omitted Holmes's principal example, the suggestion that courts might 
night work legislation, his court had "been led into error ... not from misunderstanding of the law, but from misunderstanding of the facts," namely "present-day conditions, as revealed by the labors of economists and students of the social sciences in our own country and abroad."225

Such a benign explanation, however, could not be given for Ives. The Ives court had not misunderstood the facts and was well aware of present-day conditions. ${ }^{226}$ Indeed, the court took note of the "attractive and desirable" "economic, philosophical, and moral theories," as well as statistical tables supporting workers' compensation. ${ }^{227}$ Such considerations, however, were found to be irrelevant to constitutional analysis. ${ }^{228}$ In contrast, they were of central importance when the court later upheld the reenacted legislation in Jensen. ${ }^{229}$ Indeed, the court wrote that with changes "in industrial conditions, an opinion has gradually developed, which almost universally favors a more just and economical system of providing compensation for accidental injuries to employ[ee]s as a substitute for wasteful and protracted damage suits, usually unjust in their results . .. to the employer[,] the employ[ee], [or] both." ${ }^{230}$ As Thomas Reed Powell would later write, the Jensen court "looked with new glasses” on the legislation, embracing “'economic and sociological arguments which the Ives opinion' had . . . 'dismissed as immaterial' to the legal analysis.",231

rewrite employee accident law, which was situated among the examples Cardozo did quote. See CARDOZO, supra note 23, at 117-18; Holmes, supra note 10, at 466 . In The Growth of the Law, Cardozo discussed Ives as an example of a "case where a choice of methods [property as an absolute, "[t]he method of logic . . . at work," or "logic supplemented by the social sciences"] was possible. It is quite aside from my purpose to inquire whether the choice as made was right." CARDOZO, supra note 189, at 71-73.

225. CARDOZO, supra note 23, at 80-81.

226. Closer to the mark was the observation found in the material that Cardozo chose not to include in his long quotation, discussed supra note 224, from Holmes's The Path of the Law. In the omitted material, Holmes wrote that a "fear [of socialism] has influenced judicial action.” Holmes, supra note 10, at 467. Holmes thus anticipated Ives, in which such a fear was evident, as the court wrote that if the legislature could require an employer, free of fault, to compensate an injured employee, why could it not "say to the man of wealth ... 'your neighbor is so poor that he can barely subsist; in the interest of natural justice you must divide with your neighbor.”' Ives v. S. Buffalo Ry. Co., 94 N.E. 431, 440 (N.Y. 1911).

227. Id. at 437.

228. Id.

229. Jensen v. S. Pac. Co., 109 N.E. 600, 604 (N.Y. 1915).

230. Id.

231. WITT, supra note 4, at 177 (quoting T.R. Powell, The Workmen's Compensation Cases, 32 POL. SCI. Q. 542, 552 (1917)). 


\section{LEON GREEN AND KARL LLEWELLYN: LEGAL REALISM, ENTERPRISE LIABILITY, AND LEGAL PRAGMATISM}

\section{A. The Transition to Legal Realism/Enterprise Liability}

Taken together, the legislative enactment of workers' compensation plans and the judicial erosion, and then elimination, of the privity requirement in products liability suits against manufacturers marked a turning point in American personal injury law. The combination of these developments could be seen to indicate that nineteenth-century limitations on liability were out of tune with the conditions and values of twentieth-century America. If so, would legislatures respond by enacting compensation plans tailored to accident situations beyond the workplace?

As to the judicial reform of the common law, tort law was littered with doctrines that denied recovery to persons injured by negligence. These doctrines included the traditional rules of landowner liability, the immunity afforded to governmental and charitable organizations, the doctrine of intrafamily immunity, and the defenses of contributory negligence and assumption of risk. Might we see judicial reform implemented by the process Cardozo described as "[r]ules derived by a process of logical deduction ... [breaking] down before the slow and steady and erosive action of utility and justice?”232 Indeed, might courts even follow the example of workers' compensation and adopt new strict liability rules or expand old ones?

One scholar feared that we might, in fact, see the judicial adoption of strict liability rules. Jeremiah Smith, himself a former judge, was a traditional tort theorist and no proponent of strict liability. ${ }^{233}$ Nevertheless, writing in the Harvard Law Review in 1914, Smith acknowledged that the strict liability imposed “under the Workmen's Compensation Acts [was] absolutely incongruous with the results reached under the modern common law as to various persons whose cases are not affected by these statutes."234 To illustrate this incongruity, Smith contrasted the situation of an injured employee with that of "an outsider, or a paying customer of the business [who] is damaged by pure accident in the conduct of the

232. See supra note 215 and accompanying text.

233. Wex S. Malone, Damage Suits and the Contagious Principle of Workmen's Compensation, 12 LA. L. REV. 231, 234 (1952).

234. Jeremiah Smith, Sequel to Workmen's Compensation Acts (pt. 2), 27 HARV. L. REV. 344, 363 (1914). Smith held conservative political views and deplored the workmen's compensation movement. See Malone, supra note 233, at 234. He recognized, however, that the "felt necessities" of an era are not necessarily those of a particular author. See Smith, supra, at 367-68. 
business." ${ }^{235}$ Although workers' compensation legislation provided an assurance of compensation to the employee, the common law generally afforded the outsider or paying customer "no remedy at all against the owner of the business." 236 Yet outsiders who often cannot protect themselves and who do not benefit from the business arguably have an argument for compensation "equal in justice to that of the workman.,237 Moreover, paying customers contribute to the fund out of which workers' compensation is paid and thus also have a further argument for compensation. $^{238}$

With workers' compensation firmly established, Smith feared that the "only present available method to remove the inconsistency is by bringing about a change in the existing common law, either by legislation or by judicial decisions." ${ }^{239}$ As to the latter, Smith followed the tradition of Shaw and Holmes in rejecting arguments that the courts cannot appropriately bring about such large-scale change. Specifically, he rejected the argument that "judges cannot 'make' law; that they merely discover and apply law which has always existed." 440 He also rejected the position that "judges can and do make new law on subjects not covered by previous decision; but that judges cannot unmake old law, cannot even change an existing rule of 'judge-made' law."241 He instead concluded that "judges can and do make new law; and also can and do unmake old law; i.e., law previously laid down by themselves or by their judicial predecessors."242

Smith did not suggest that judicial adoption of strict liability rules would occur overnight. "When courts change the substantive law," he wrote, "they generally do so very gradually, and often attempt to conceal (or perhaps unconsciously conceal) the fact of change by using various 'fiction phrases.",243 Smith also suggested that change could occur indirectly "[b]y a very liberal construction of the res ipsa loquitur doctrine; by a broad view as to what constitutes prima facie evidence of negligence;

235. Jeremiah Smith, Sequel to Workmen's Compensation Acts (pt. 1), 27 HARV. L. REV. 235, 237 (1914).

236. Id.

237. Id. at 252.

238. Id. at 253-54.

239. Smith, supra note 234, at 363.

240. Id. at 365.

241. Id. at 366 .

242. Id.

243. Id. 
and by inverting the burden of proof (putting on defendant the burden of proving that he was not negligent)."244

Despite the fears of Smith and others, tort law and scholarship during the first quarter of the twentieth century continued to be dominated by legal formalism and traditional tort theory, both of which stood in opposition to courts creating new avenues to recovery. Traditional theorists rejected strict liability as "not tolerable" because it conflicted with "the fundamental proposition of the common law which links liability to fault." 245 The leading torts scholar of this period was Francis Bohlen, who was the Reporter for the Restatement of Torts. ${ }^{246}$ Although a supporter of workers' compensation legislation ${ }^{247}$ and the abrogation of the privity requirement in the products cases, ${ }^{248}$ Bohlen equated the common law of torts with the negligence requirement and the defense of contributory negligence. He also rationalized doctrines that immunized defendants, such as landowners, from negligence liability on the ground that persons have no affirmative duty to protect others unless there is a corresponding benefit. ${ }^{249}$ For traditional theorists, "tort" law was synonymous with the negligence requirement and ancillary immunity rules; workers' compensation was a legislative program of insurance, irrelevant to tort analysis.

Although traditional tort theory continued its dominance, ideas that we would identify today as the early stirrings of the theory of enterprise liability theory emerged sporadically in the 1910s and 1920s in the form of proposals for legislatively enacted compensation plans. Some authors simply urged the extension of the workers' compensation principle to workers-such as railway employees and harbor workers-who were

244. Id. at 367

245. See Ezra Ripley Thayer, Liability Without Fault, 29 HARV. L. ReV. 801, 814, 815 (1916). See generally Jeremiah Smith, Liability for Substantial Physical Damage to Land by Blasting-The Rule of the Future (pt. 1), 33 HARV. L. Rev. 542, 550 (1920) ("The history of law as to the former absolute liability in the absence of fault, and as to the present general requirement of fault as a requisite to liability, can be stated very briefly. Speaking generally, the modern law is a reversal of the ancient law.... At the present time, it is the general rule that fault is requisite to liability.”).

246. See WhITE, supra note 58, at 78-79; George L. Priest, The Invention of Enterprise Liability: A Critical History of the Intellectual Foundations of Modern Tort Law, 14 J. LEgAL STUD. 461, 466 (1985).

247. See Francis H. Bohlen, A Problem in the Drafting of Workmen's Compensation Acts (pts. 1-3), 25 HARV. L. REV. 328, 401, 517 (1912).

248. See Francis H. Bohlen, Liability of Manufacturers to Persons Other than Their Immediate Vendors, 45 LAW Q. REV. 343, 343, 369 (1929).

249. See Francis H. Bohlen, The Basis of Affirmative Obligations in the Law of Tort (pt. 2), 53 U. PA. L. REV. 273, 273 \& n.2 (1905). 
not covered by state worker compensation legislation. ${ }^{250}$ More provocative was a 1916 proposal of a compensation plan "based upon ... the workmen's compensation acts" for passengers injured while traveling by "railroad and street railway," the largest "class of cases in most city courts" at that time. ${ }^{251}$ The proposal's author, Arthur A. Ballantine, urged "liability irrespective of negligence" coupled with "limited liability" because, in his view, "the cost of the transportation service should include the expense of insuring the passenger." 252 However, the "rapidly expanding volume of motor vehicle accident litigation" soon eclipsed the importance of railway accidents, and in 1919, an author argued that the analogy to employee accidents and workers' compensation "suggested ... the application of similar principles to the troublesome problem of motor vehicle accident losses."253 The idea of an automobile compensation plan was picked up and pursued in a flurry of articles in the mid-1920s. ${ }^{254}$ These compensation plan proposals were early manifestations of the emerging enterprise liability theory.

The focus of writers such as Ballantine on legislative reform of tort law is easily understood. Most obviously, the legislative successes of the workers' compensation movement inspired reformers to look optimistically to the legislatures for further innovation. More fundamentally, these reformers could well have concluded that they had little choicethat legislation was the only practical route to achieving the goals of enterprise liability. Courts in the hold of legal formalism and traditional tort theory-and whose ideological outlook had been demonstrated in

250. See, e.g., John B. Andrews, Complete the Circle of Compensation, 15 AM. LAB. LEGIS. REV. 285, 285-87 (1925) (proposing a federal compensation plan for railway employees and harbor workers).

251. Arthur A. Ballantine, A Compensation Plan for Railway Accident Claims, 29 HARV. L. REV. 705, 705, 707 (1916).

252. Id. at 708

253. Ernest C. Carman, Is a Motor Vehicle Accident Compensation Act Advisable?, 4 Minn. L. Rev. 1, 1, 2 (1919); see also Shippen Lewis, Accident Litigation, 72 U. PA. L. REV. 400, 410 (1924) (discussing a compensation plan for persons injured by a train, trolley, or automobile).

254. See Wayland H. Elsbree \& Harold Cooper Roberts, Compulsory Insurance Against Motor Vehicle Accidents, 76 U. PA. L. ReV. 690, 690-91 (1928); Harry J. Loman, Compulsory Automobile Insurance, 130 Annals AM. ACAD. Pol. \& SoC. SCI. 163, 163, 170 (1927); Robert S. Marx, Compulsory Automobile Insurance, 1 U. CIN. L. REV. 445, 445-46 (1927); Robert S. Marx, Compulsory Automobile Insurance, 11 A.B.A. J. 731, 731 (1925); Robert S. Marx, Compulsory Compensation Insurance, 25 ColuM. L. ReV. 164, 164 (1925); Robert S. Marx, The Curse of the Personal Injury Suit and a Remedy, 10 A.B.A. J. 493, 493 (1924). 
the Ives decision-were unlikely sources of reform. It is no wonder then that these reformers had not asked whether workers' compensation plans might serve as a model for changes in the common law. Nor did they speculate about the implications for tort law of the social philosophy these plans represented. And they did not ask whether MacPherson might lead to parallel developments in a field such as landowner liability. These matters, however, would become the focus of two of the seminal scholars of the next generation, the Legal Realists Leon Green and Karl Llewellyn.

\section{B. The Legal Realists' Constitutional Restraint and Common Law Creativity}

During the 1920s and 1930s, a cluster of scholars emerged whose views on judicial lawmaking carried on the tradition of Shaw, Holmes, and Cardozo - thus diverging from both Pound and the formalists. Prominent among these scholars, whose jurisprudential views are today identified with Legal Realism, were Leon Green and Karl Llewellyn, two giants in American law. In the constitutional realm, Green and Llewellyn joined mainstream scholars such as Roscoe Pound in opposition to Lochner-style nullification of social and economic legislation —and in the call for judicial deference to the legislature. ${ }^{255}$

The major focus of Green's and Llewellyn's scholarship, however, was not constitutional law. Green focused on tort law, and Llewellyn focused on contract and sales law. It was in these areas that their jurisprudential views most clearly departed from those of Pound. When they focused on the common law, and in Llewellyn's case, replacing the obsolete Uniform Sales Act, Green and Llewellyn followed the path forged by Shaw and Holmes and embraced by Cardozo.

In the face of formalists who denied that courts make law and scholars such as Pound who saw a narrowing judicial lawmaking role, Green and Llewellyn recognized the reality, inevitability, and desirability of judicial lawmaking - and the central role that social policy plays in that process. The jurisprudential view of Green and Llewellyn was simple and clear: in the common law realm, courts (1) do make law and (2) such lawmaking is so obviously desirable, necessary, and in our common law tradition that it needs no fancy jurisprudential justification-beyond, that is, arguments as to the substantive desirability of particular proposals.

255. Leon Green, Unpacking the Court, New Republic, Feb. 24, 1937, at 67, 6768; K. N. Llewellyn, A United Front on the Court, NATION, Mar. 13, 1937, at 288, 28889. 


\section{Leon Green's Legal Realism and Enterprise Liability}

In a 1929 article, Green vehemently rejected the staples of traditional tort theory, declaring that "[c]urrent legal theory ... is wholly inadequate."256 Scornful of talk about a "tort of negligence," Green wrote that "[t]his can only be intended in a catchword sense." 257 In practice, negligence law countenanced "ruthless" defenses ${ }^{258}$ and no-duty rules noted for their "harshness." 259 Such doctrines granted classes of defendants a preferential position against which "[e]ven the strong morality of the negligence theory has made slow progress." 260

Indeed, the cornerstone of traditional tort theory, the "idea of 'fault' . . . had become bankrupt.", 261 As to the reverence given to "principles" by traditional theorists, Green wrote that “'principles' are nothing more than the generalizations (assumptions) drawn from the factors which determined the initial judgment." 262 It followed that "these factors having changed, the initial judgment should no longer stand. 'Principles' should therefore be expected to vary as do the factors which support them . . .."263

In place of traditional analysis, Green offered his own scheme for determining both common law duties and whether compensation plans should displace tort law in particular categories of accidents - or situation types. Green urged a focus on five factors: (1) the administrative factorthe practical workability of a rule; (2) the moral factor - or considerations of fault; (3) the economic factor-including the impact on economic activity; (4) the prophylactic factor-concerned with the prevention of future harm; and (5) the justice factor - seen as "synonymous [with] the capacity to bear the loss." 264 This last factor, which envisioned an inquiry into loss spreading capacity as an aspect of tort theory, was truly revolutionary, and traditional theorists recognized this at the time. Francis Bohlen, for example, wrote that the "so-called 'Justice' factor ... has no place in a restatement of the existing law of the United States and not that of Utopia.

256. Green, supra note 33, at 276.

257. Id. at 279 (internal quotation marks omitted).

258. Id. at 264-66.

259. Id. at 274.

260. Id. at 271.

261. Id. at 270 .

262. Id. at 280

263. Id.

264. Id. at 255-57; Calvert Magruder, Book Review, 45 HARv. L. Rev. 412, 415 (1931) (reviewing LEON GREEN, JUDGE AND JURY (1930)). 
This factor has never consciously or ... unconsciously influenced the decision of any court ....,265

Unlike traditional tort theorists who viewed workers' compensation plans as irrelevant to "tort,"266 the law of employee accidents was the cornerstone of Green's analysis, providing "a pattern by which to indicate other developments either mature or now underway."267 The enactment of workers' compensation plans signaled that "a new order of things was at hand" and marked a recognition that "risks of physical hurts could be distributed as well as could wages and other costs." 268 In Green's hands, this recognition became the policy of "plac[ing] the loss where it will be felt the least and can best be borne." ${ }^{269}$ He argued that accidental injury was not a product of moral shortcoming but the "inevitable" byproduct of industrial society. ${ }^{270}$ Moreover, the "costs of affording . . . protection can be cared for as part of the costs of the enterprise, and more than all ... the risk when it results in hurt ... can best be borne and absorbed" by the enterprise. ${ }^{271}$ This insistence that the capacity to bear and distribute a loss was a legitimate consideration in tort law injected a vital new element into tort analysis, legitimizing the loss spreading policy that would become central to what became known as the theory of enterprise liability.

Bearing in mind that the same policy, or duty, factors are relevant to both the legislative and the common law agenda, it is instructive to see the far-reaching implications of these factors by briefly examining Green's legislative strategy. For Green, the workers' compensation "pattern”,272 suggested that "the question now has come to be, not whether the negligence process should be recognized as controlling [in specific classes of cases], but whether [classes of cases] should not be controlled . . . by even a more rational process for imposing responsibility."273 This more rational process would be legislatively enacted compensation plans based on the workers' compensation model, and Green proposed compensation plans for "general traffic cases," 274 for railway crossing accidents, ${ }^{275}$ and for children injured while trespassing on the premises

265. Francis H. Bohlen, Book Review, 80 U. PA. L. REV. 781, 794 (1932) (reviewing GREEN, supra note 264).

266. E.g., Warren A. Seavey, Principles of Torts, 56 HARV. L. REv. 72, 86 (1942).

267. Green, supra note 33, at 270.

268. Id.

269. Id. at 256.

270. Id. at 278 .

271. Id. at 273

272. Id. at 270 .

273. Id. at 271

274. Id. at 277-78

275. Id. at 274-75. 
of industrial landowners. ${ }^{276}$ Green intended these proposals to be suggestive, not exhaustive. He wrote that the "possibilities are many" and that he had merely chosen "familiar subject matters" to illustrate the "pattern ... [of] developments either mature or now under way."277

Unlike Pound, who had called for narrowing the lawmaking role of courts, Green envisioned courts reforming tort law to achieve the goals of enterprise liability. Examining cases allowing recovery for trespassers injured on a defendant's property, Green noted that under basic tort doctrine, a landowner "owe[d] a trespasser no duty other than not to intentionally harm him." ${ }^{278}$ Breaking from traditional analysis, however, Green rejected the "assumption (stated in the decisions as a principle) ... that all landowners are to be subjected to the same responsibility."279 In his view, special problems arose out of a particular situation type-cases involving "industrial land owners." ${ }^{, 280}$ In cases involving trespassers injured on these industrial premises, courts had been able to impose liability for negligence through a process of “"peaceful penetration' ... [although] negligence [could not] yet wear its own garb."281 In his finding that courts singled out industrial premises cases for special treatment, Green's analysis confirms Brian Leiter's claim that judicial "decisions fall into patterns correlated with the underlying factual scenarios of the disputes," as opposed to formal "legal rules.,"282

Moreover, within the industrial landowner cases, Green believed that particular situation types could be singled out. He found that courts had allowed a negligence cause of action for young children injured by dangerous and attractive machinery on industrial property, which evolved into the child trespasser rule. ${ }^{283}$ Also, in cases of adults trespassing on industrial property, courts had required railways to keep a lookout for such persons and had required other industrial landowners to warn or otherwise protect them from hidden dangers and to refrain from negligent action while such persons were present. ${ }^{284}$ Judges in these cases were able to provide “"bootleg' protection” by "bend[ing] both principles ...

276. Id. at 272-73.

277. Id. at 270 .

278. Id. at 271.

279. Id. at 274 .

280. Id. at 272

281. Id. at 271.

282. Leiter, supra note 31, at 1148.

283. Green, supra note 33, at 272-73.

284. Id. at 274. 
and judgment ... long before [they overcame] their own habits of talking about such matters in the refined categories of 'fault.",285

In Green's view, courts in these cases were responding to his policy, or duty, factors. He wrote that the ability of industrial enterprises, such as railroads and factories, "to reduce the risks of hurt even as to those who insist upon subjecting themselves to such risks, is sufficient to warrant judgment for plaintiffs in many of these cases." ${ }^{\text {,86 }}$ Moreover, "the costs of affording such protection can be cared for as part of the costs of the enterprise." 287 And "more than all ... the risk when it results . . can best be borne and absorbed by this type of landowner." 288 Summarizing the application of his duty factors to child trespasser cases, Green wrote that "[e]very consideration of economics, of ethics, of prevention, and of justice would all place a severe duty upon the landowner in such cases.,289

Green's approval of the "good result"290 reached by affording such "bootleg protection"291 can be seen as implicit normative advice that lagging courts should move in that direction. But he also had bigger fish to fry, and here Green-and Llewellyn, as we will soon see-contradict Brian Leiter's claim that the Legal Realists offered little, if any, normative advice to courts. ${ }^{292}$

Noting that the judgments of courts in these premises cases were "years in advance of their language," Green wrote that the "normal negligence formula of 'reasonable care under all the circumstances' was designed for just these cases in which judgment must have the widest range and in which uniformity, except in process, is impossible."293 Green thus urged that courts, based on his policy factors, do what no court had done or would do for decades: hold that landowners owe a full duty of care to adult - and presumably child - trespassers - and presumably licenseeson industrial property. Four decades later, the California Supreme Court would write policy factors derived from Green into law in its landmark Rowland v. Christian decision abolishing the traditional landowner rules. ${ }^{294}$

Green's normative agenda, moreover, extended beyond reforms within the negligence system. Contrary to traditional theorists who viewed the

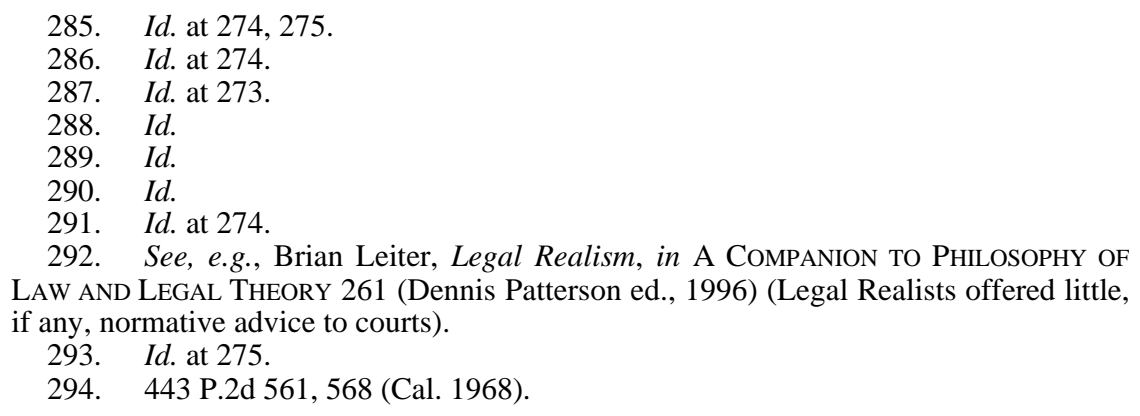


strict liability rule of Rylands v. Fletcher ${ }^{295}$ as "misguided,"296 Green suggested that courts might adopt strict liability rules, which could simplify litigation and assure compensation. Noting that the "extreme use of power in Rylands v. Fletcher was not as misguided as sometimes thought," Green approved of a 1928 California Supreme Court decision, Green v. General Petroleum Corp. ${ }^{297}$ that applied strict liability to a defendant whose oil well had blown out while being drilled with due care. ${ }^{298}$

The far-reaching implications of Green's analysis can be seen in a twopart article published in 1929 and 1930 by Lester Feezer and "prepared under the direction of Dean Leon Green.”299 Elaborating on Green's position that courts and legislatures could legitimately decide to "place the loss where it will be felt the least and can best be borne," ${ }^{, 300}$ Feezer suggested that courts might apply strict liability rules to vehicle operators by building on Rylands v. Fletcher. ${ }^{301}$

\section{Karl Llewellyn's Legal Realism and Strict Products Liability}

Although Green had recognized that courts might expand the reach of Rylands-style strict liability rules, his focus on tort law meant that he neglected the warranty doctrines of sales law that permitted courts to impose strict liability in cases of injury caused by food products. ${ }^{302}$ It was out of these warranty decisions that the modern law of strict products liability grew and an aggressive common law strategy developed. The seminal scholar was Karl Llewellyn, ${ }^{303}$ who addressed the issue of products liability in his 1930 casebook on the law of sales and in a 1936 article. ${ }^{304}$

295. (1868) 3 L.R.E. \& I. App. 330 (H.L.).

296. Green, supra note 33, at 282.

297. 270 P. 952 (Cal. 1928).

298. Green, supra note 33, at 282.

299. L.W. Feezer, Capacity To Bear Loss as a Factor in the Decision of Certain Types of Tort Cases (pt. 2), 79 U. PA. L. REV. 742, 742 n.1 (1931).

300. Green, supra note 33, at 256.

301. L.W. Feezer, Capacity To Bear Loss as a Factor in the Decision of Certain Types of Tort Cases (pt. 1), 78 U. PA. L. REV. 805, 813 (1930).

302. For an early account of the application by courts of strict liability in food cases, see Rollin M. Perkins, Unwholesome Food as a Source of Liability (pts. 1 \& 2), 5 IOWA L. BuLL. 6, 86 (1919-1920).

303. For an excellent discussion of Llewellyn's sales scholarship, see Zipporah Batshaw Wiseman, The Limits of Vision: Karl Llewellyn and the Merchant Rules, 100 HARV. L. REV. 465 (1987).

304. LLEWELLYN, supra note 36, at 341-42; Llewellyn, supra note 36, at 704 n.14; see also K.N. Llewellyn, The Effect of Legal Institutions upon Economics, 15 AM. Econ. 
When a "court proclaims a 'warranty' and therefore a recovery" in the food products cases, Llewellyn wrote, it is not "a case of 'warranty' as we know it in mercantile sales law [but rather] a technical excuse for shifting a risk which seems to call for shifting." 305 Warranty law was "being stretched . . . to fit a . . need." ${ }^{\text {,306 }}$ As Llewellyn explained, "How could case-law grow, without technical defects? You cannot both really follow, and get results, at once. Since you have to seem to follow, and also have to get results, almost every advance is at the price of fudging your logic." 307

The "tendencies toward ... which [these cases were] driving" was indicated by what Llewellyn called the "ideal picture" ${ }^{308}$ : "If judges were legislators, and felt free of precedent; ... if the courts were given to viewing social policy as a whole, rather than the particular case before them; ... . the goal of the development would ... have been clear.",309 The "needed protection," Llewellyn wrote, "is twofold: to shift the immediate incidence of the hazard of life in an industrial society away from the individual over to a group which can distribute the loss; and to place the loss where the most pressure will be exerted to keep down future losses." ${ }^{310}$ It followed, for Llewellyn, that strict liability should be imposed on manufacturers who are "equipped to spread, and indeed to reduce, risks." ${ }^{111}$ The suggestion that tort law might serve as an incentive to reduce accident losses, as well as Green's prophylactic factor, anticipated the later economics-oriented scholarship.

This was the "ideal picture," and Llewellyn wrote that it was "time for legislation," presumably to enact this broad rule of strict products

REV. 665, 665-83 (1925) (providing early presentation of related views). For a detailed account of Llewellyn's contribution to the development of strict products liability, see John B. Clutterbuck, Note, Karl Llewellyn and the Intellectual Foundations of Enterprise Liability Theory, 97 YALE L.J. 1131 (1988).

305. LLEWELLYN, supra note 36, at 343.

306. Id.

307. Llewellyn, supra note 36, at 705 n.14.

308. LLEWELLYN, supra note 36, at 342.

309. Id. at 341.

310. Id. In 1920, Rollin M. Perkins, in supporting application of strict liability in food cases, had seen such liability as "stimulating such great care that the injury will be avoided.” Perkins, (pt. 2), supra note 302, at 110. A 1924 analysis by Edwin W. Patterson had suggested that the warranty doctrine applied in food cases should be analyzed in terms of risk bearing. Edwin W. Patterson, The Apportionment of Business Risks Through Legal Devices, 24 Colum. L. Rev. 335, 357-59 (1924). Patterson was concerned that the "theory of contracts" posed privity barriers to recovery from manufacturers by injured consumers. Id. at 358. "[O]nly by some violent pounding and twisting can the [warranty] concept be made to yield the result called for by considerations of economic and social policy." Id. Thus, Patterson asked, "Would it not simplify matters to state the rules as one of . . . risk-bearing?” Id.

311. Llewellyn, supra note 36, at 704 n.14. 
liability. ${ }^{312}$ Although he did not elaborate on this terse suggestion in his 1930 casebook or 1936 article, Llewellyn did take steps to implement it in his preparation of what would become the Uniform Commercial Code. ${ }^{313}$ As to the role of courts, it should be noted that not all courts were imposing strict liability in food cases. Thus, Llewellyn can be seen as offering implicit normative advice to courts who were "hampered in their vision" "314: they should join the trend of the warranty line of decisions that, by "fudging [their] logic,"315 had allowed recovery in food cases and that "waxe[d] great by way of glass in beverages or bread, and poisonous meat." 316 Moreover, Llewellyn did not see this development as "confined to [the food cases], its center. It spreads to cover other hazards to consumers." 317 And Llewellyn's "ideal picture" of a broad strict liability doctrine indicated "a set of tendencies toward ... which [the cases were] driving.”318

The implications of Llewellyn's analysis can be seen in a 1938 article by Lester Feezer, which incorporated in quotation form two pages of material from Llewellyn's 1930 casebook. ${ }^{319}$ Writing that "Professor Llewellyn has outlined the situation,"320 Feezer argued that the food cases

312. LLEWELLYN, supra note 36, at 342.

313. In the 1930s, Llewellyn and others began to contemplate the possibility of replacing the "rebuilt machine" of the Uniform Sales Act with a new creation, which would eventually become the Uniform Commercial Code. Id. at xvi; Wiseman, supra note 303, at 475. In 1940 and 1941, Llewellyn proposed, as part of his new law of sales, a manufacturer's implied warranty of freedom from dangerous defects. This warranty would impose an "absolute liability ... on manufacturers for injury 'in person or property' incurred by anyone 'in the ordinary course of use or consumption ... by reason of the defect in the goods." ' Wiseman, supra note 303, at 507 (quoting Revised Uniform Sales Act 1941 (Report and Second Draft) at § 16-B(r)). Llewellyn's proposed sales law was considered in the National Conference of Commissioners on Uniform State Laws beginning in 1940. Id. at 482. Merchants' representatives voiced such strong opposition at the 1941 conference that Llewellyn dropped the warranty provision entirely. Asked about the deletion at the 1943 meeting, "Llewellyn replied that 'every time we tried to draw' the rule, it [so] 'scare[d] everybody that saw it pea green.” Id. at 523 n.255 (quoting NCC Proceedings (1943) at 105).

314. LLEWELLYN, supra note 36, at 342.

315. Llewellyn, supra note 36, at 705 n.14.

316. LLEWELLYN, supra note 36, at 342.

317. Id.

318. Id

319. Lester W. Feezer, Manufacturer's Liability for Injuries Caused by His Products: Defective Automobiles, 37 MicH. L. REV. 1, 5-6 (1938) (quoting LLEWELLYN, supra note 36 , at 340-42).

320. Id. at 6 . 
"furnish[ed] a convenient stepping stone for the inclusion of other manufactured articles in the same category."321 Building on this case law, Feezer "suggest[ed] the possibility that makers of all sorts of products [would] be held responsible ... without showing negligence." ${ }^{\text {322 }}$ Such a rule would fulfill the policy of placing the burden "where it can be best distributed." 323

\section{E. The Pragmatic Jurisprudence of the Legal Realists}

With their combination of common law and compensation plan strategies, their recognition that courts could "fudge their logic" to reach enterprise liability goals, and their willingness to look both to tort and sales law to craft new doctrines, the jurisprudence of the Legal Realists could be characterized by the word pragmatic. And Fowler Harper, a contemporary of Green and Llewellyn, made precisely this point in a brief 1929 article surveying developments in both the constitutional and common law realms. ${ }^{324}$ In that article, Harper coined the term juristic pragmatism and thus foreshadowed Judge Posner's later use of the term legal pragmatism. ${ }^{325}$

Harper wrote that "[a]s law for Justice Holmes means prophecies of what the court will do; so, just law for the pragmatist jurist means prophecies of what will produce the most satisfactory and most desired consequences. ${ }^{\text {} 326}$ And either legislatures or courts could produce this law. Thus, Harper wrote, judicial decisions that even in the midst of the Lochner era "made possible the great flood of social legislation . . . completely revolutionizing the legal conception of 'due process of law,' proceed from a deep-rooted pragmatist thinking.”327 Similarly, "[s]tatutes alleviating conditions of employment ... have higher working values than decisions which emanated from natural law but left the laborer 'free to starve.",328

Moreover, "[t]he common law ... affords constant evidences of the juristic pragmatism which alone can solve its philosophic problems.”329 Leon Green's tort scholarship provided Harper with his common law example. ${ }^{330}$ In examining conflicting case law on the effect of the violation

321. Id. at $10-11$.

322. Id. at 26.

323. Id. at 24.

324. See Harper, supra note 38, at 273-74.

325. Id. at 275.

326. Id. at 273-74.

327. Id. at 285 .

328. Id. (footnoted omitted) (quoting Knoxville Iron Co. v. Harbison, 183 U.S. 13

(1901)).

329. Id. at 286.

330. See id. at 286-87. 
of a statute, Green had written that " $\mathrm{t}]$ he question was one of sound policy, and the Wisconsin court took one view while the Vermont court took the other." "331 As to which was right, Green observed that "[i]t is a matter of judgment, good taste, an interpretation of the community's desires; in short, law making." 332 Harper wrote that "when jurists talk of judicial decision, not in terms of a logically determined system . . . but in terms of 'judgment,' 'good taste,' and 'interpretation of the community's desire,' they are talking in terms of working hypotheses, offensive to any form of natural law."333 For Harper, this type of analysis was "juristic pragmatism." 334

Like Holmes and Cardozo, Green and Llewellyn recognized that courts have a legislative as well as an adjudicatory role-and that policy plays a role in their lawmaking. All four of these seminal figures are the equivalent of Judge Posner's legal pragmatist who believes that at times "judges in our system are legislators as well as adjudicators" and that policy judgments are at the core of their lawmaking. ${ }^{335}$

\section{LEGAL PRAGMATISM AND ENTERPRISE LIABILITY IN THE COURTS}

Llewellyn's, and Feezer's, proposal for strict products liability was picked up by Prosser in his 1941 treatise, ${ }^{336}$ and then, importantly, by Justice Roger Traynor of the California Supreme Court in his 1944 concurring opinion in Escola v. Coca Cola Bottling Co. ${ }^{337}$ Traynor wrote that the "cost of an injury and the loss of time or health may be an overwhelming misfortune to the person injured.”338 This misfortune, however, is “a needless one, for the risk of injury can be insured by the manufacturer and distributed among the public as a cost of doing business."339 Traynor

331. Id. at 286 (quoting Leon Green, Contributory Negligence and Proximate Cause, 6 N.C. L. REV. 3, 15 (1927)).

332. Id. (quoting Green, supra note 331, at 15).

333. Id. at 286-87.

334. Id. at 287.

335. POSNER, supra note 2, at 118, 238. Brian Leiter has recognized as much in noting that what he calls "nonquietist” Legal Realists could be seen as "'Proto-Posnerians,' to mark their anticipation of a view familiar in our own day.” Brian Leiter, American Legal Realism, in The BlackWell Guide to the Philosophy of LAW AND LEgal TheORY 50, 58 (Martin P. Golding \& William A. Edmundson eds., 2005).

336. See William L. ProsSER, HANDBOOK OF THE LAW OF TORTS § 83, at 689 (1941).

337. See 150 P.2d 436, 440 (Cal. 1944) (Traynor, J., concurring).

338. Id. at 441.

339. Id. 
emphasized, moreover, that "public policy demands that responsibility be fixed wherever it will most effectively reduce the hazards to life and health inherent in defective products that reach the market. It is evident that the manufacturer can anticipate some hazards and guard against the recurrence of others, as the public cannot."340

Recognizing the still dominant place held by legal formalism in legal thinking, Traynor, in a series of articles beginning in 1956, joined Holmes, Cardozo, Green, and Llewellyn in insisting that judicial responsibility "connotes the recurring formulation of new rules to supplement or displace the old" and "the recurring choice of one policy over another." 341 For Traynor, the "real concern is not the remote possibility of too many creative opinions but their continuing scarcity." the law, far from being unduly accelerated by judicial boldness, is unduly hampered by a judicial lethargy that masks itself as judicial dignity with the tacit approval of an equally lethargic bar."343

Beginning in the 1960s, judicial lethargy gave way to the California Supreme Court's embrace of a pragmatic jurisprudence whose outlines follow the contours sketched by Holmes, Cardozo, and the Legal Realists. Under Traynor's guidance, the California Supreme Court became an occasional—and in some fields frequent-legislator, with policy at the heart of its lawmaking. By the 1970s, Grant Gilmore wrote, the court had become "the most innovative court in the country." "344 The consequence of that innovation, the editors of the Harvard Law Review wrote in 1970, was a "dramatic renaissance of the common law."345 And nowhere was that renaissance more evident than in tort law.

Both the strict liability doctrine and its underlying policies were written into California law beginning in the 1960s with Greenman v. Yuba Power Products, Inc. ${ }^{346}$ Based on these policies, the California Supreme Court, with little hesitation, extended strict liability beyond manufacturers to include retailers, ${ }^{347}$ wholesalers, ${ }^{348}$ and lessors. ${ }^{349}$ These rulings, which courts across the nation quickly followed, represented, according to

340. Id. at $440-41$.

341. R. J. Traynor, The Courts: Interweavers in the Reformation of Law, 32 SASK. L. REV. 201, 213 (1967).

342. Roger J. Traynor, Comment on Courts and Lawmaking, in LEGAL InSTITUTIONS TODAY AND TOMORROW 48, 52 (Monrad G. Paulsen ed., 1959).

343. Id.

344. Grant GILMORE, The DeAth OF Contract 91 (1974).

345. 83 HARV. L. REV. 1769, 1769 (1970).

346. See 377 P.2d 897, 900-01 (Cal. 1963).

347. See Vandermark v. Ford Motor Co., 391 P.2d 168, 171-72 (Cal. 1964).

348. See Canifax v. Hercules Powder Co., 46 Cal. Rptr. 552, 557 (Ct. App. 1965).

349. See Price v. Shell Oil Co., 466 P.2d 722, 723, $726-27$ (Cal. 1970). 
Prosser, "the most rapid and altogether spectacular overturn of an established rule in the entire history of the law of torts."350

The Legal Realists' normative agenda met similar success within negligence law. In 1968, for example, the California Supreme Court, in its landmark decision in Rowland v. Christian, wrote policy factors that can be traced to Green into California tort law as it discarded the traditional landowner rules in favor of a general duty of due care. ${ }^{351}$ More generally, the court held that the fundamental principle is that liability generally should be imposed for an "injury occasioned to another by want of ordinary care or skill.”

Just as in the case of its landmark strict products liability rulings, so too the California Supreme Court's approach to duty has proved influential with the nation's courts, as illustrated by the Restatement (Third) of Torts. ${ }^{353}$ Like California, the Restatement adopts a default rule that defendants owe a duty of reasonable care to avoid physical injury. ${ }^{354}$ Also, like California, the determination that a no-duty rule should be

350. William L. Prosser, Handbook of the LaW of TorTs § 97, at 654 (4th ed. 1971).

351. 443 P.2d 561, 567 (Cal. 1968). Rowland adopted and augmented factors first articulated by the court in Biakanja v. Irving, 320 P.2d 16, 19 (Cal. 1958). Biakanja, in turn, drew on and augmented factors found in Prosser's hornbook. See FowLER V. HARPer \& Fleming James, JR., The LAW of TorTs § 18.6, at 1052 (1956); Prosser, supra note 350, § 30, at 164-68. Prosser's factors were an adaptation of the duty factors Green articulated in his Duty Problem articles.

In deciding whether to retain, discard, or modify traditional no-duty rules in the future, courts would consider

the foreseeability of harm to the plaintiff, the degree of certainty that the plaintiff suffered injury, the closeness of the connection between the defendant's conduct and the injury suffered, the moral blame attached to the defendant's conduct, the policy of preventing future harm, the extent of the burden to the defendant and consequences to the community of imposing a duty to exercise care with resulting liability for breach, and the availability, cost, and prevalence of insurance for the risk involved.

Rowland, 443 P.2d at 564. Rowland's duty factors would provide the framework for California decisions expanding the concept of duty in later years, but with a more conservative court in the past quarter century, they also provided the framework for cutting back liability. Compare Isaacs v. Huntington Mem'l Hosp., 695 P.2d 653, 658-59, 66163 (Cal. 1985) (emphasizing foreseeability and expanding landowner duty to protect against crime by third parties), with Ann M. v. Pac. Plaza Shopping Ctr., 863 P.2d 207, 214-15 (Cal. 1993) (limiting Isaacs).

352. Rowland, 443 P.2d at 563.

353. Restatement (ThiRd) OF TORTS: Liability for PhysicAl AND EMOTIONAL HARM $\S 7$ (2005).

354. Id. 
adopted is a determination of policy or, in the words of the Restatement, "[a] principle or policy [that] warrants denying or limiting liability." 355 Although the Restatement declines to delineate factors to assist in this policy determination, a substantial number of states have followed Rowland in this regard, and half the nation's courts have followed Rowland in establishing a unitary standard of care in premises cases, at least with respect to invitees and licensees. ${ }^{356}$

As a consequence of judicial appointments by Republican governors, the court since the 1980s has been a conservative court. Yet the jurisprudence of this court has reflected that of its predecessor. It also is an avowedly lawmaking court, with-this time conservative-policies at the heart of its lawmaking. This court has refined or cut back on-but in most cases not abandoned - the enterprise liability doctrines put in place by its predecessors. ${ }^{357}$

355. Id.

356. See W. Jonathan Cardi \& Michael D. Green, Duty Wars, 81 S. CAL. L. Rev. 671, 676 n.27 (2008) (citing RESTATEMENT (THIRD) OF TORTS: LIABILITY FOR PHYSICAL AND EMOTIONAL HARM $\S 51$ reporters' note to cmt. a (Council Draft No. 7, 2007)).

357. See, e.g., Ann M. v. Pac. Plaza Shopping Ctr., 863 P.2d 207, 214-15 (Cal. 1993) (limiting duty of business premises owner to protect persons against violent thirdparty crime); Knight v. Jewett, 834 P.2d 696, 712 (Cal. 1992) (abolishing traditional consent-based defense of assumption of risk and establishing a new no-duty rule for coparticipants in recreational sports); Thing v. La Chusa, 771 P.2d 814, 815 (Cal. 1989) (restricting recovery for negligent infliction of emotional distress). 